\title{
Hyperpolarization-activated cyclic nucleotide gated channels: a potential molecular link between epileptic seizures and $A \beta$ generation in Alzheimer's disease
}

Yuhki Saito', Tsuyoshi Inoue ${ }^{2}$, Gang Zhu ${ }^{3}$, Naoki Kimura', Motohiro Okada ${ }^{4}$, Masaki Nishimura ${ }^{5}$, Nobuyuki Kimura ${ }^{6}$, Shigeo Murayama ${ }^{7,8}$, Sunao Kaneko ${ }^{9}$, Ryuichi Shigemoto ${ }^{10}$, Keiji Imoto ${ }^{11}$ and Toshiharu Suzuki ${ }^{*^{*}}$

\begin{abstract}
Background: One of the best-characterized causative factors of Alzheimer's disease (AD) is the generation of amyloid- $\beta$ peptide (A $\beta$ ). AD subjects are at high risk of epileptic seizures accompanied by aberrant neuronal excitability, which in itself enhances $A \beta$ generation. However, the molecular linkage between epileptic seizures and $A \beta$ generation in $A D$ remains unclear.

Results: $\mathrm{X} 11$ and $\mathrm{X} 11$-like $(\mathrm{X} 11 \mathrm{~L})$ gene knockout mice suffered from epileptic seizures, along with a malfunction of hyperpolarization-activated cyclic nucleotide gated (HCN) channels. Genetic ablation of HCN1 in mice and HCN1 channel blockage in cultured Neuro2a (N2a) cells enhanced A $\beta$ generation. Interestingly, HCN1 levels dramatically decreased in the temporal lobe of cynomolgus monkeys (Macaca fascicularis) during aging and were significantly diminished in the temporal lobe of sporadic AD patients.

Conclusion: Because HCN1 associates with amyloid- $\beta$ precursor protein (APP) and X11/X11L in the brain, genetic deficiency of $X 11 / X 11 \mathrm{~L}$ may induce aberrant HCN1 distribution along with epilepsy. Moreover, the reduction in HCN1 levels in aged primates may contribute to augmented A $\beta$ generation. Taken together, HCN1 is proposed to play an important role in the molecular linkage between epileptic seizures and $A \beta$ generation, and in the aggravation of sporadic AD.
\end{abstract}

\section{Background}

Alzheimer's disease $(\mathrm{AD})$ is characterized by progressive memory impairment, which accompanies aging. Genetic and biochemical studies show that the production of amyloid- $\beta$ peptide $(A \beta)$ largely contributes to the etiology of $A D[1] . A \beta$ is generated from amyloid- $\beta$ precursor protein (APP) by $\beta$ - and $\gamma$-cleavage of the latter.

The risk of seizure activity is particularly high in $\mathrm{AD}$ patients, with an 87-fold increase in subjects with earlyonset dementia compared with an age-matched reference population [2-7]. Factors linking seizure activity to $A \beta$ generation in $A D$ patients remain unclear, although epilepsy is believed to result from abnormal regulation

\footnotetext{
* Correspondence: tsuzuki@pharm.hokudai.ac.jp

${ }^{1}$ Laboratory of Neuroscience, Graduate School of Pharmaceutical Sciences, Hokkaido University, Kita12-Nishi6, Kita-ku, Sapporo 060-0812, Japan Full list of author information is available at the end of the article
}

of neuronal excitability, which favors hypersynchrony. In addition, increased neuronal activity enhances $A \beta$ production from APP [8-10].

Hyperpolarization-activated cyclic nucleotide gated $\mathrm{HCN}$ channels 1-4 (HCN1-4) conduct inward, depolarizing mixed $\mathrm{Na}^{+} / \mathrm{K}^{+}$currents and thereby control resting membrane potential, dendritic integration, synaptic transmission, and rhythmic activity in cardiac pacemaker cells and spontaneous firing neurons [11]. Dysregulation of these channels and their hyperpolarization-activated (Ih) currents is strongly implicated in various experimental animal models of epilepsy, as well as in human epilepsy patients [12]. Furthermore, HCN2 co-assembles with the $\mathrm{X} 11$-like (X11L) protein [13], which is a metabolic regulator of APP processing [14].

X11 proteins (X11s) comprise a family of three evolutionarily conserved molecules (X11/X11 $\alpha /$ Mint1, X11L/

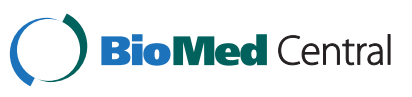


$\mathrm{X} 11 \beta /$ Mint2, and X11L2/X11 $\gamma /$ Mint3). These proteins bind to the cytoplasmic region of APP in cultured cells and suppress its metabolism $[15,16]$. Moreover, the metabolism of overexpressed human APP (hAPP) is suppressed in X11 and X11L transgenic mice, along with the generation of $A \beta$ [17-19]. On the other hand, mutant mice lacking $\mathrm{X} 11 \mathrm{~L}\left(\mathrm{X} 11^{+/+} / \mathrm{X}_{11 L^{-/-}}\right.$mice$)$or both $\mathrm{X} 11$ and

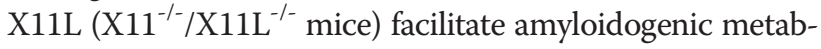
olism of endogenous murine APP and exogenous hAPP, including $A \beta$ generation [20-22]. Therefore, inactivation of $\mathrm{X} 11 / \mathrm{X} 11 \mathrm{~L}$ clearly increases the production of $\mathrm{A} \beta$, potentially contributing to the pathology of $\mathrm{AD}$.

Here, we report that i) $\mathrm{X} 11^{-/-} / \mathrm{X} 11 \mathrm{~L}^{-/-}$mice suffer from spontaneous epileptic seizures along with malfunction of HCN channel activity; ii) $\mathrm{HCN} 1$ can form a complex with $\mathrm{APP}$ and $\mathrm{X} 11$ or X11L in the murine brain; iii) $\mathrm{HCN1}^{-1-}$ gene knockout mice show enhanced $A \beta$ generation; iv) overexpression of $\mathrm{HCN} 1$ in Neuro2a (N2a) cells decreases $A \beta$ generation, whereas blockage of $\mathrm{HCN} 1$ channel activity in N2a cells restores the level of $A \beta$ production; v) the level of HCN1 diminishes significantly in the temporal cortex of cynomolgus monkeys (Macaca fascicularis) during aging; and vi) HCN1 levels are significantly reduced in the brains of sporadic AD patients compared with the brains of age-matched healthy subjects.
Given the previous reports and our current observations, we hypothesize that X11 and X11L play an important role in the modulation of $\mathrm{HCN}$ channel function, the dysregulation of which correlates with epilepsy. We further hypothesize that the impairment of $\mathrm{HCN}$ channels, and in particular $\mathrm{HCN} 1$, accompanies with the aberrant production of $A \beta$, which manifests as neurotoxicity. Thus, HCN1 together with X11 and X11L may provide a molecular link between seizure activity and $A \beta$ generation in AD patients.

\section{Results}

Spontaneous epileptic seizures caused by X11 and X11L gene deficiency

Electrocorticograms were recorded in $\mathrm{X}_{1} 1^{+/+} / \mathrm{X}_{11 L^{+/+}}$ (wild type), $\mathrm{X} 11^{+/+} / \mathrm{X}_{11 \mathrm{~L}^{-/}}, \mathrm{X}_{1} 1^{-/-} / \mathrm{X}_{11 \mathrm{~L}^{+/+}}$, and $\mathrm{X} 11^{-/-} /$ $\mathrm{X} 11 \mathrm{~L}^{-/-}$mice. We found that $\mathrm{X} 11^{-/-} / \mathrm{X} 11 \mathrm{~L}^{-/-}$mice suffered from spontaneous epileptic seizures at the age of 13 weeks and over (detailed results are provided in Additional file 1: Figure S1 and Additional file 2: Movies S1, Additional file 3: Movies S2 and Additional file 4: Movies S3). Three

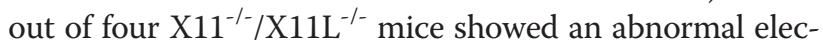
trocorticogram recording within $48 \mathrm{~h}$, namely, the presence of epileptic discharge, which were never observed in $\mathrm{X} 11^{+/+} / \mathrm{X} 11 \mathrm{~L}^{+/+}, \mathrm{X} 11^{+/+} / \mathrm{X} 11 \mathrm{~L}^{-/-}$, or $\mathrm{X} 11^{-/-} / \mathrm{X} 11 \mathrm{~L}^{+/+}$

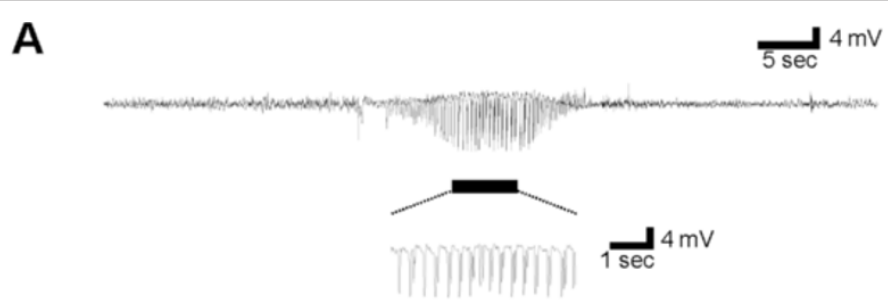

B

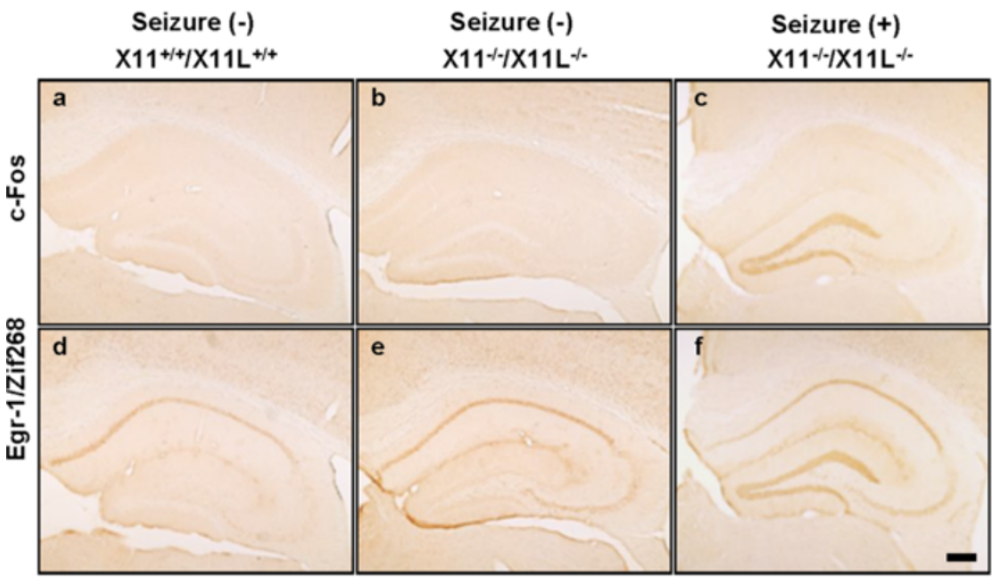

Figure 1 Electrocorticogram recording and histological changes associated with epileptic seizures in $X 11^{-/-} / \mathrm{X} 11 \mathrm{~L}^{-/-}$mice. $(A)$ An

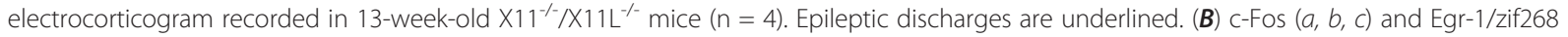
$(d, e, f)$ immunoreactivity in the hippocampus of $X 11^{+/+} / X 11 L^{+/+}(a, d)$ and $X 11^{-1 /} / X 11 L^{-1-}(b, c, e, f)$ mice under steady-state conditions $(a, b, d, e)$ and at $90 \mathrm{~min}$ after an epileptic episode $(c, f)$. Scale bar, $200 \mu \mathrm{m}$. 
mice (Figure 1, Additional file 1: Figure S1 and Additional file 4: Movie S3). Subsets of $\mathrm{X} 11^{-/-} / \mathrm{X} 11 \mathrm{~L}^{-/-}$mice went into status epilepticus and died.

Seizures are often associated with the augmented expression of immediate-early genes in neurons [23]. We first asked whether such gene activation was observed in $\mathrm{X} 11^{-/-} / \mathrm{X} 11 \mathrm{~L}^{-/-}$mice following epileptic seizures and investigated the involvement of specific brain regions in seizure activity. Brain tissue sections from $\mathrm{X} 11^{-/-} / \mathrm{X} 11 \mathrm{~L}^{-/-}$mice were immunostained for c-Fos, a calcium-dependent immediate-early gene product, and Egr-1/Zif268, an early growth response transcription factor, within $90 \mathrm{~min}$ of a seizure event. The brains of these mice showed enhanced expression of both c-Fos and Egr-1/Zif268 in the dentate gyrus (DG) granule cells compared with the brains of $\mathrm{X} 11^{+/+} / \mathrm{X} 11 \mathrm{~L}^{+/+}$and $\mathrm{X} 11^{-/-} / \mathrm{X} 11 \mathrm{~L}^{-/-}$mice (Figure 1B). However, we cannot rule out a possibility that subclinical discharges without aberrant behavior may

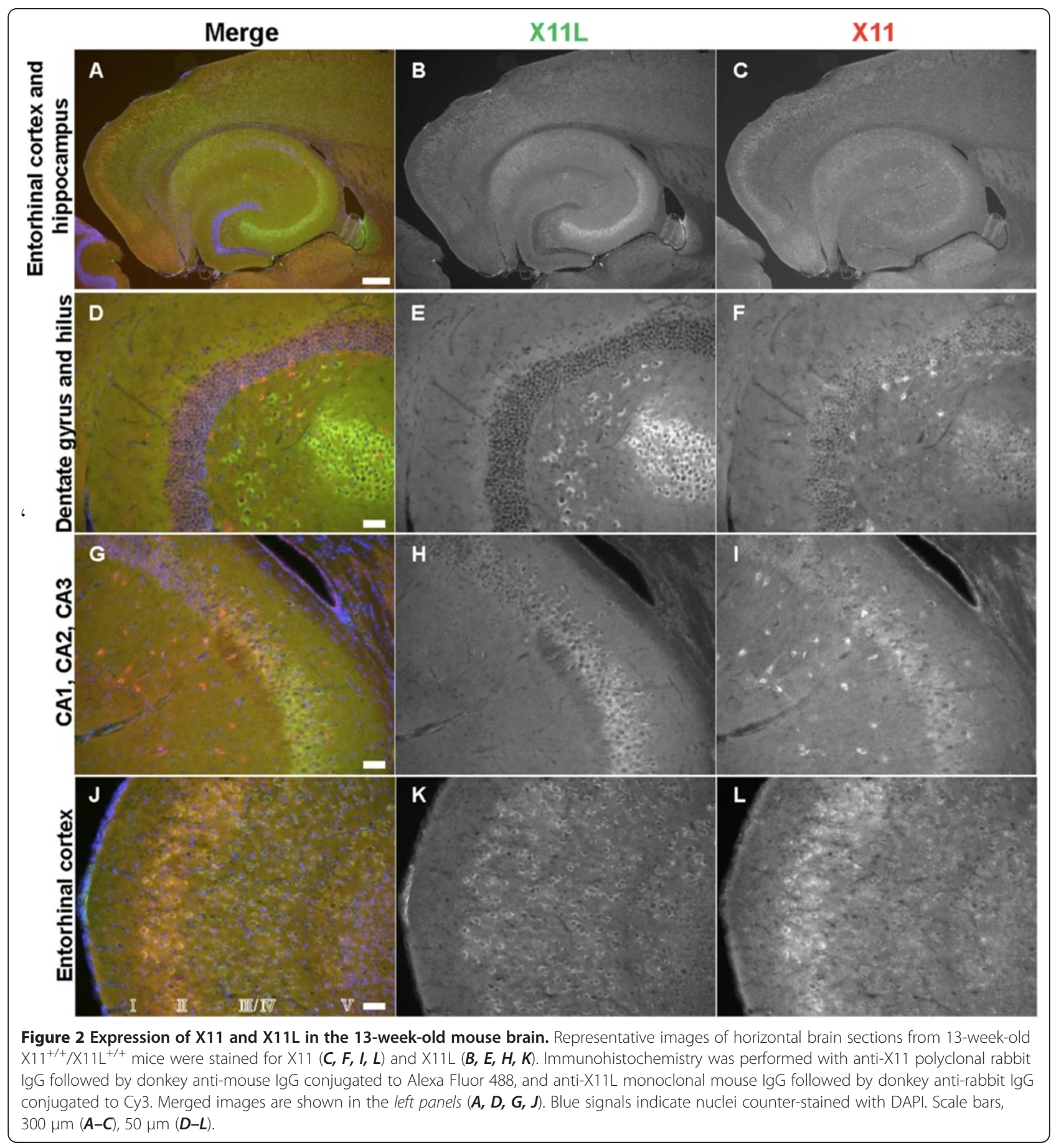


cause the enhanced expression of c-Fos and Egr-1/Zif268. Thus, a deficiency in both X11 and X11L may cause abnormal, seizure-associated neuronal activity and subsequent alterations in protein expression in the hippocampal formation.

\section{Reduction of Ih currents in entorhinal cortex (EC) layer II of $\mathrm{X} 11^{-/ /} / \mathrm{X} 11 \mathrm{~L}^{-/-}$mice}

Spontaneous epileptic seizures were observed in mice when both X11 and X11L genes were deficient (Figure 1A, Additional file 1: Figure S1 and additional movies). Because the DG granule cells of $\mathrm{X}_{1} 1^{-/} / \mathrm{X} 11 \mathrm{~L}^{-/-}$mice showed augmented expression of c-Fos and Egr-1/Zif268 following seizure activity, we next performed a detailed examination of the expression of both proteins in hippocampal neurons in 13-week-old murine brains (Figure 2).

Distinct expression patterns of X11 and X11L were observed in the hippocampus of wild type mice. X11L was expressed mainly in the pyramidal neurons of the CA1-3 region (Figure 2B, E, H), whereas X11 was expressed in other types of interneurons (Figure 2C, F, I). These observations coincide with our previous report of X11s expression in aged wild type mice [21]. Unlike c-Fos and Egr-1/Zif268 in the double mutant mouse, X11 and X11L were not expressed in DG granule cells (Figure 2D-F). However, both X11 and X11L were strongly coexpressed in EC layer II (Figure 2J-L), which projects axons primarily to the granule cells of the DG [24]. Furthermore, both $\mathrm{HCN} 1$ and $\mathrm{HCN} 2$ are expressed in EC layer II [25]. Given that $\mathrm{HCN1}^{-1-}$ mice show enhanced seizure susceptibility and that $\mathrm{HCN}_{2}{ }^{-1-}$ mice suffer from absence seizures [26,27], we next focused our investigations on the alteration of Ih currents associated with $\mathrm{HCN}$ channels in EC layer II in $\mathrm{X}_{1} 1^{-/-}$, $\mathrm{X} 11 \mathrm{~L}^{-1-}$ mice.

Horizontal brain slices that included the EC and the hippocampus were prepared from 12-14-week-old

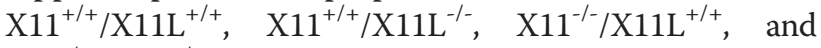
$\mathrm{X} 11^{-/ /} / \mathrm{X} 11 \mathrm{~L}^{-1-}$ mice. EC layer II neurons were then subjected to electrophysiological analysis, and Ih currents from HCN channels were recorded (Figure 3 and Additional file 1: Figure S2). The mice used in the electrophysiological study were seizure-naïe, at least without over behavioral manifestations, and showed comparable levels of HCN1 channels in the EC (Additional file 1: Figure S3). Similar to a previous report [28], hyperpolarizing voltage steps activated a large Ih current in EC layer II cells of $\mathrm{X} 11^{+/+} / \mathrm{X}_{11 L^{+/+}}$mice (Figure $3 \mathrm{~A}$ and $\mathrm{C}$ ). By contrast, the Ih current was dramatically reduced in $\mathrm{X} 11^{-/-} / \mathrm{X} 11 \mathrm{~L}^{-/-}$ mice relative to that in $\mathrm{X}_{11}^{+/+} / \mathrm{X}_{11 \mathrm{~L}^{+/+}}$mice (Figure 3B and $\mathrm{D}$ ); however, no significant alterations were observed

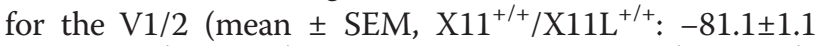

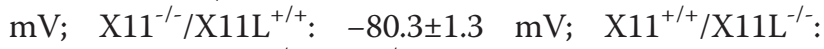

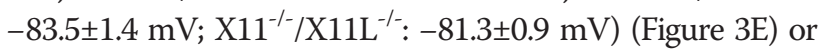

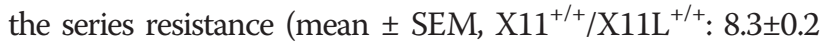

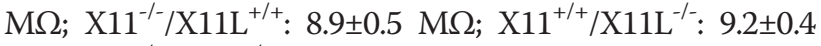

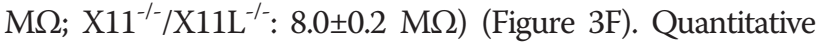
analysis (Figure 3G) revealed that the density of the Ih current was also significantly reduced in $\mathrm{X}_{1} 1^{-1} / \mathrm{X}_{11} \mathrm{~L}^{-/-}$mice $(1.12 \pm 0.15 \mathrm{pA} / \mathrm{pF}, \mathrm{n}=9 ; p<0.01)$ compared with that in

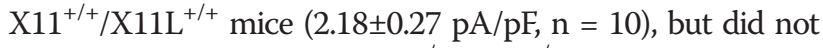
change significantly in $\mathrm{X}_{1} 1^{-/} / \mathrm{X} 11 \mathrm{~L}^{+/+}$mice $(2.41 \pm 0.25$ $\mathrm{pA} / \mathrm{pF}, \mathrm{n}=9, p>0.05)$ or in $\mathrm{X} 11^{+/+} / \mathrm{X}_{11} \mathrm{~L}^{-/-}$mice $(2.05 \pm 0.29$ $\mathrm{pA} / \mathrm{pF}, \mathrm{n}=9, p>0.05)$. Thus, genetic ablation of X11 and $\mathrm{X} 11 \mathrm{~L}$ together had a profound impact on the Ih current in the EC layer II of the double knockout mice. These results correlate with the observation that $\mathrm{X} 11^{-/-} / \mathrm{X}_{11} \mathrm{~L}^{-/-}$mice, but not $\mathrm{X} 11^{+/+} / \mathrm{X}_{11} \mathrm{~L}^{+/+}, \mathrm{X}_{1} 1^{+/+} / \mathrm{X}_{11} \mathrm{~L}^{-/-}$, or $\mathrm{X}_{1} 1^{-/} / \mathrm{X}_{11 L^{+/+}}$mice, are susceptible to spontaneous epileptic seizures.

In EC layer II, the dominant $\mathrm{HCN}$ subtype is $\mathrm{HCN} 1$ [28]. We found that HCN1, X11, and X11L were colocalized in EC layer II neurons (Figure $3 \mathrm{H}$ ) and apparently formed a complex in the brain (Figure 3I-K). The colocalization of these molecules was observed in a region surrounding the neuronal nucleus (Figure 3H), consistent with the location of the Golgi apparatus. Because X11 and X11L are largely localized in the Golgi apparatus and function in the trafficking of membrane proteins $[29,30]$, the deletion of X11 and X11L may disturb intracellular localization of $\mathrm{HCN}$ channels (Additional file 1: Figure S4). While the localization of the channel likely affects its function, we cannot rule out the possibility that X11 and X11L directly regulate $\mathrm{HCN} 1$ function as well.

\section{Enhanced $A \beta$ generation according to $\mathrm{HCN} 1$ dysfunction}

The EC is one of the most vulnerable brain regions in $\mathrm{AD}$ [31], and it is well-known that synaptic activity such as that mediated by $\mathrm{HCN}$ channels can regulate $\mathrm{A} \beta$ generation [8-10]. Therefore, we examined whether $\mathrm{HCN}$ channel impairment involved in the aberrant production of $\mathrm{A} \beta$. We first quantified the levels of endogenous $\mathrm{A} \beta 40$ and $\mathrm{A} \beta 42$ in $\mathrm{HCN1}^{-1-}$ mouse brains. $\mathrm{A} \beta 40$ and A $\beta 42$ were both significantly increased in the cortex of $\mathrm{HCN1}^{-1-}$ mice compared with $\mathrm{HCN1}^{+/+}$mice (average \pm SEM, A 440: $\mathrm{n}=5, p=0.0037 ; \mathrm{A} \beta 42: \mathrm{n}=5, p=0.0055$ ) (Figure 4A). The magnitude of the increase in $A \beta 40$ and A 342 was inversely proportional to the level of $\mathrm{HCN} 1$ gene expression (Figure 4A, left panel), while APP protein levels were comparable in $\mathrm{HCN1}^{+/+}, \mathrm{HCN1}^{+/-}$, and $\mathrm{HCN1}^{-1-}$ mice (Figure 4A, right panel).

To confirm whether the increase in $A \beta$ generation in $\mathrm{HCN1}^{-1-}$ mice depends on the decrease in $\mathrm{HCN}$ channel activity, we used N2a cells that transiently overexpressed FLAG-APP and HCN1 (Figure 4B). Overexpression of $\mathrm{HCN} 1$ significantly reduced the generation of $A \beta 40$ and A $\beta 42$ (compare column 2 with column 3 for each $A \beta$ peptide). The A $\beta$ levels were restored by adding ZD7288, a 


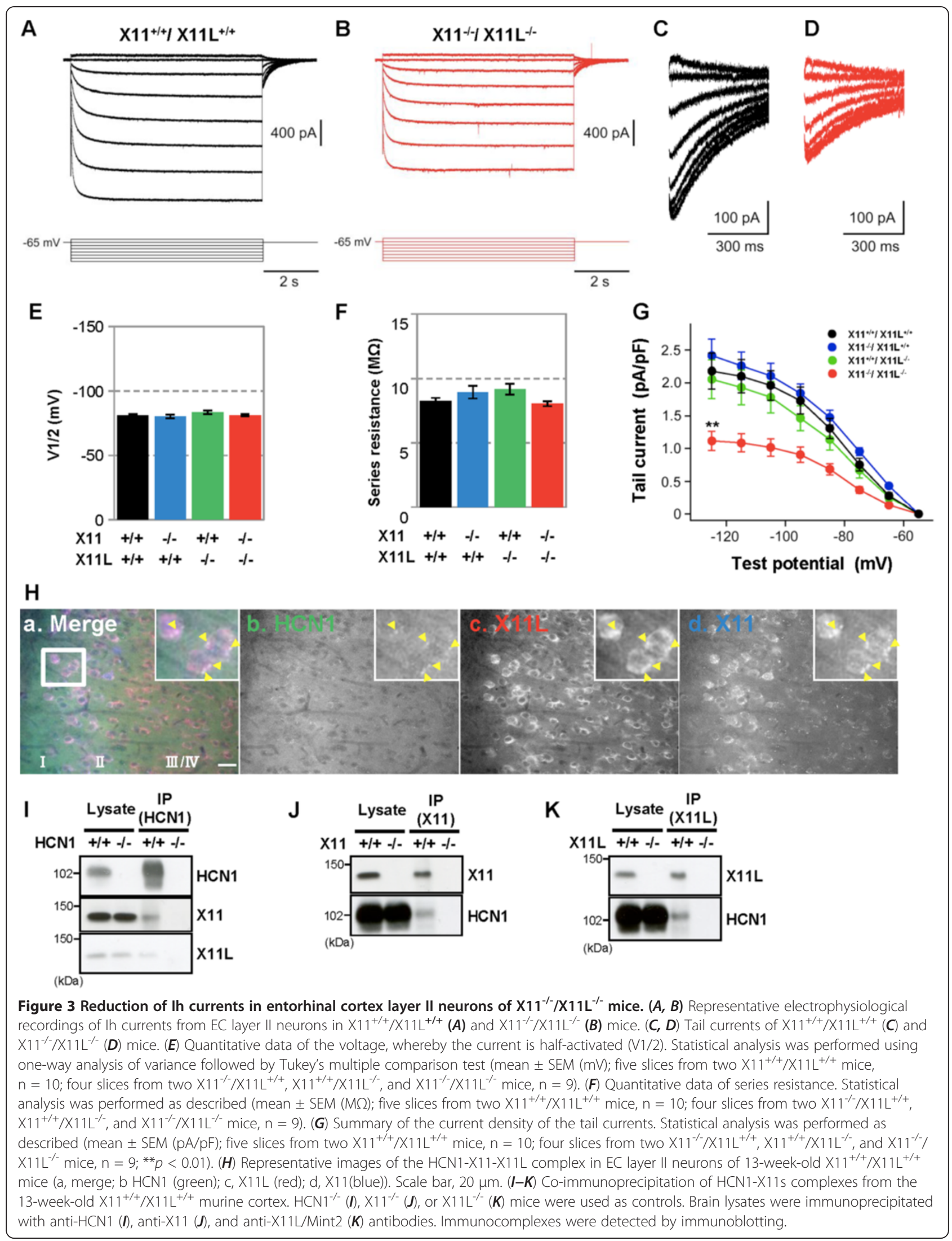


A

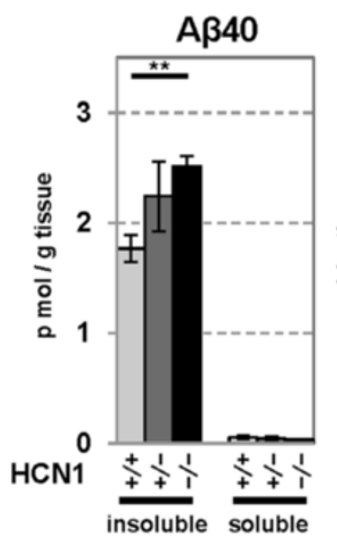

B

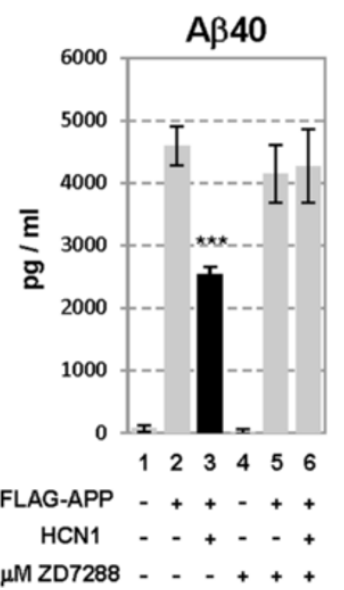

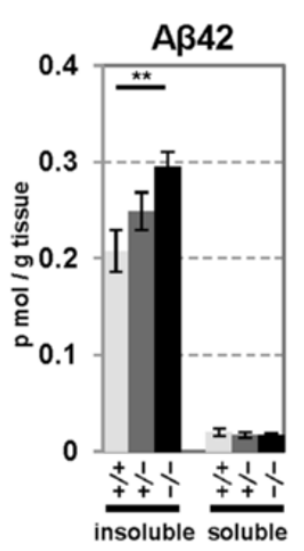

HCN1 $+1++1-+++++-\%$
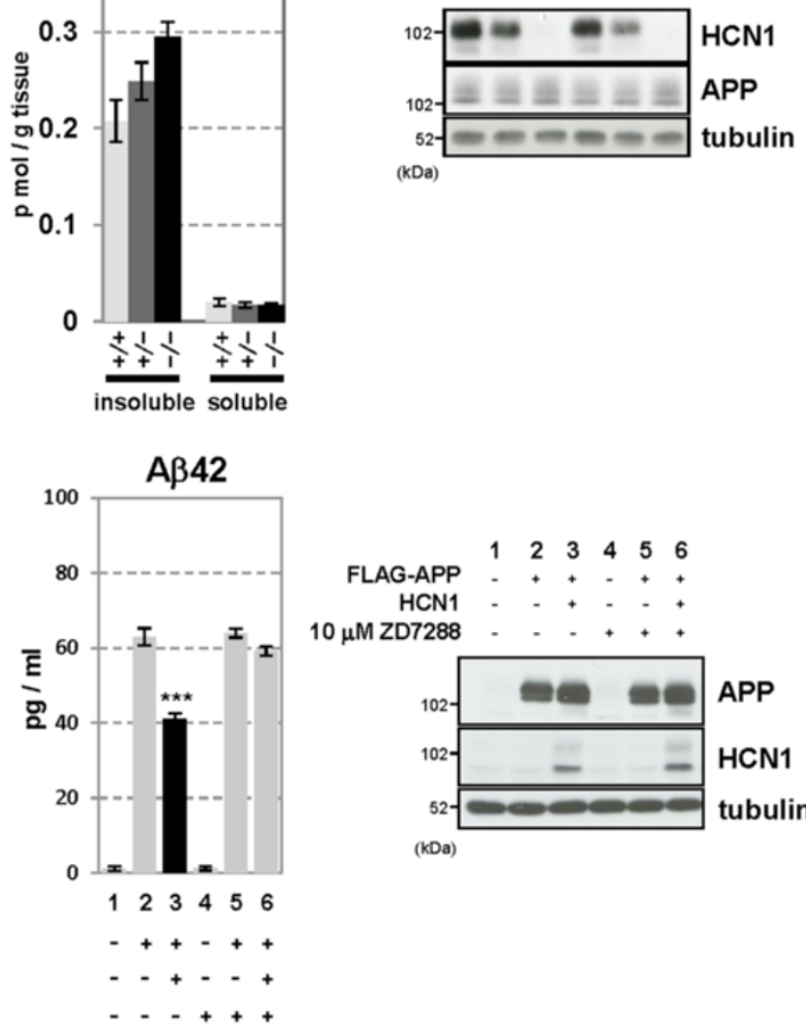

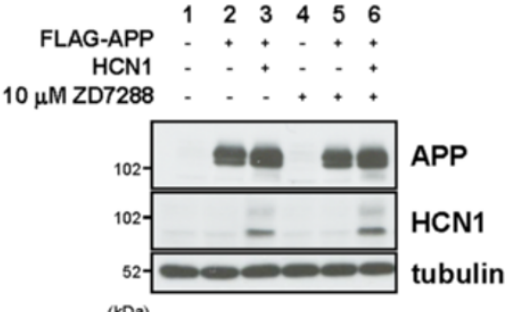

$(\mathrm{kDa})$

Figure 4 Functional deficits in the HCN1 channel facilitate $\mathbf{A} \boldsymbol{\beta}$ generation. (A) Quantification of endogenous murine $A \beta 40$ and $A \beta 42$ in the cortex of 4-month-old $\mathrm{HCN1}^{+/+}, \mathrm{HCN1}^{+/-}$, and $\mathrm{HCN1}^{-/-}$mice by using the sELISA system (left panels). Statistical analysis was performed using the two-tailed Mann-Whitney U-test (average $\pm S E M, n=5,{ }^{* *} p<0.01$ ). (B) Quantification of $A \beta 40$ and $A \beta 42$ secreted into the culture medium by N2a cells by using the sELISA system. FLAG-APP or FLAG-APP and HCN1 were transiently overexpressed in the cells with (+) or without $(-) 10 \mu M$ ZD7288 (left panels). Statistical analysis was performed using one-way analysis of variance followed by Tukey's multiple comparison test (average $\pm \mathrm{SEM}, \mathrm{n}=4,{ }^{* * *} \mathrm{p}<0.001$ ). Expression levels of APP and HCN1 was confirmed by immunoblotting (right panels in $\boldsymbol{A}$ and $\boldsymbol{B}$ ).

selective inhibitor of $\mathrm{HCN}$ channel activity (compare lanes 3 through 6). Although we have not confirmed the blockage of channel activity electrophysiologically, ZD7288 had no effect on $A \beta$ levels in cells without $\mathrm{HCN1}$ expression (column 5), and APP expression was not affected by either the presence of $\mathrm{HCN} 1$ or by the administration of ZD7288 (Figure 4B, right panel). Furthermore, administration of ZD7288 did not influence the interaction of HCN1 with APP (Additional file 1: Figure S5). These results suggest that the suppression of $A \beta$ generation in $\mathrm{HCN} 1$ overexpressing cells probably depends on channel activity (Figure 4B), in agreement with the in vivo observation that the brains of mice lacking the $\mathrm{HCN} 1$ gene and with impaired HCN channel activity (Figure 3B, D, and G) demonstrated increased $A \beta$ generation (Figure $4 \mathrm{~A}$ ).

\section{Association of HCN1 with APP in vivo and in vitro}

Increased synaptic activity enhances $A \beta$ generation [8-10], and modulation of $A \beta$ generation is not limited to alterations in HCN1 channel activity. Indeed, APP metabolism is thought to be largely regulated by APP-binding partners [14]. Therefore, we next explored the hypothesis that HCN1 might be involved in regulating APP metabolism via a physical interaction between the channel and APP. In support of this hypothesis, an anti-HCN1 antibody co-immunoprecipitated APP together with HCN1 from a lysate of wild type murine cortex (Figure 5A). The interaction seemed to be specific in that APP was not recovered from the cortical lysate of $\mathrm{HCN}^{-1-}$ mice. The association between APP and HCN1 was next confirmed in the EC. Using EC-rich brain samples isolated from $\mathrm{HCN}^{+/+}$and $\mathrm{HCN}^{-1-}$ mice (Additional file 1: Figure S3A), a co-immunoprecipitation assay was performed with an anti-HCN1 antibody, and the immunoprecipitates were analyzed with the indicated antibodies (Figure 5B). Along with X11 and X11L, APP was co-immunoprecipitated with $\mathrm{HCN} 1$ in EC-rich brain samples of wild type mice (Figure 5B), suggesting that $\mathrm{HCN} 1$ can complex with 
$\mathrm{APP}$ and $\mathrm{X} 11 / \mathrm{X} 11 \mathrm{~L}$ in vivo. These results are in agreement with the co-localization results of HCN1, X11, and $\mathrm{X} 11 \mathrm{~L}$ in the wild type cortex shown above (Figure $3 \mathrm{H}-\mathrm{K}$ ). Tubulin and PSD95 (postsynaptic density protein 95) were not detected in the immunocomplex, indicating the specific association of APP and X11/X11L with $\mathrm{HCN} 1$.

To show whether HCN1 directly binds to APP without mediation by X11/X11L, FLAG-APP and HCN1 were transiently expressed in $\mathrm{N} 2 \mathrm{a}$ cells and a co-immunoprecipitation

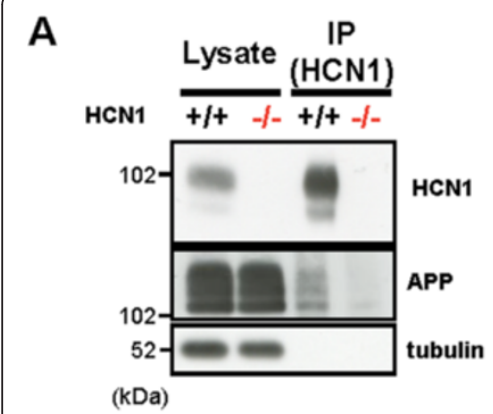

D

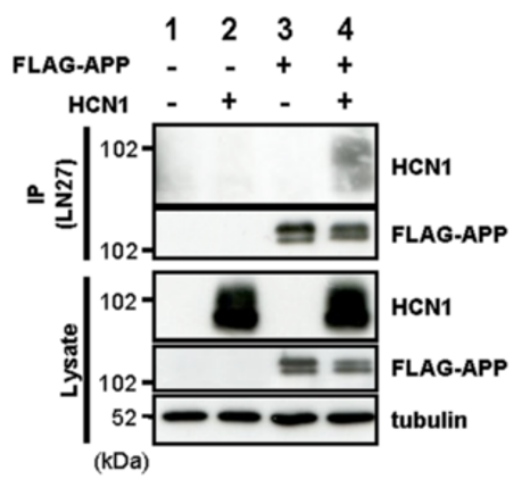

G

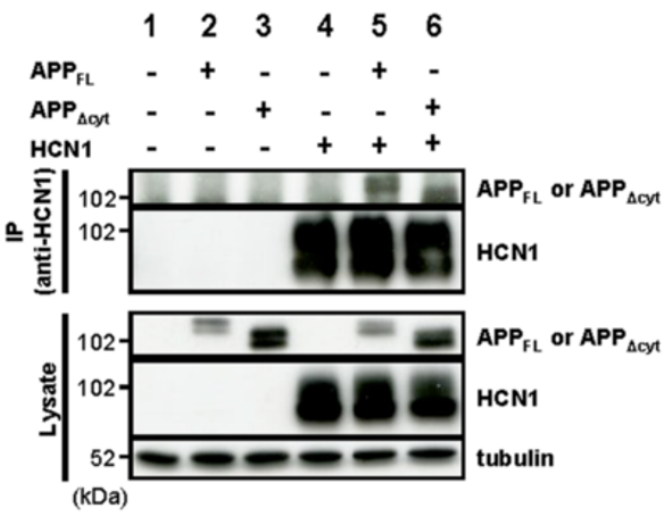

Figure 5 (See legend on next page.)

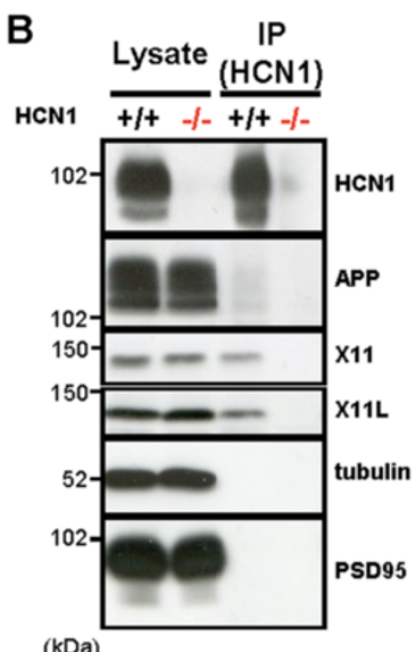

E

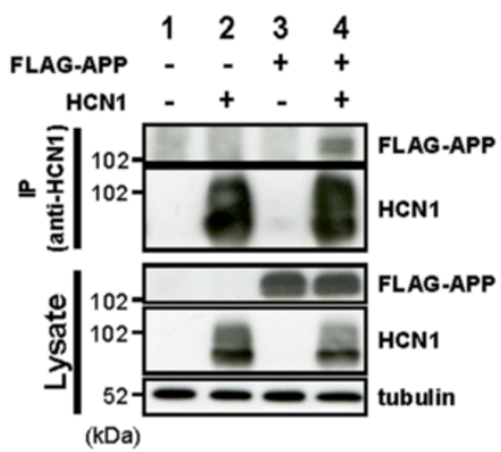

H

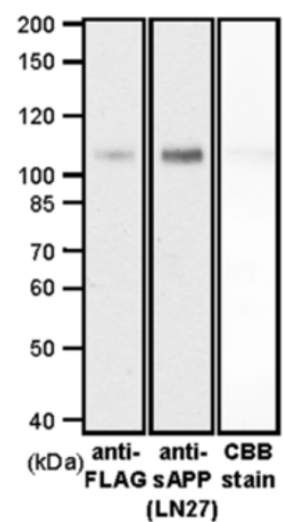

$$
\text { (LN27) }
$$

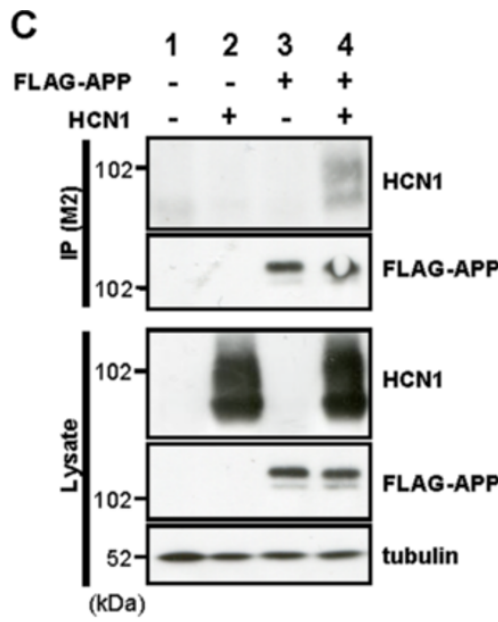

$\mathbf{F}$

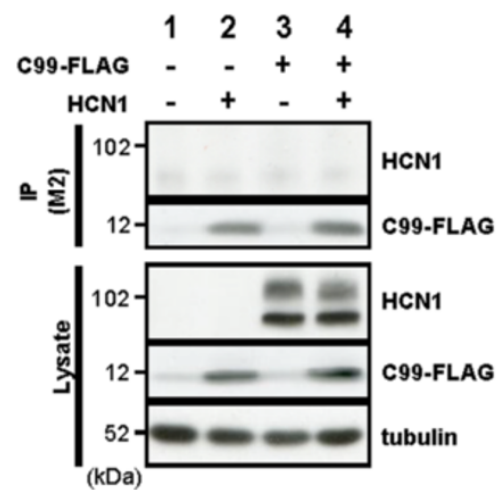

I

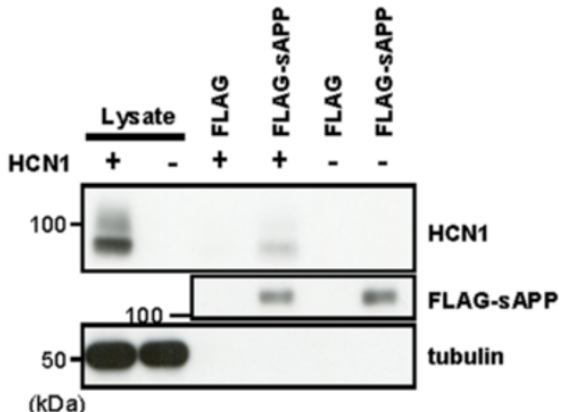




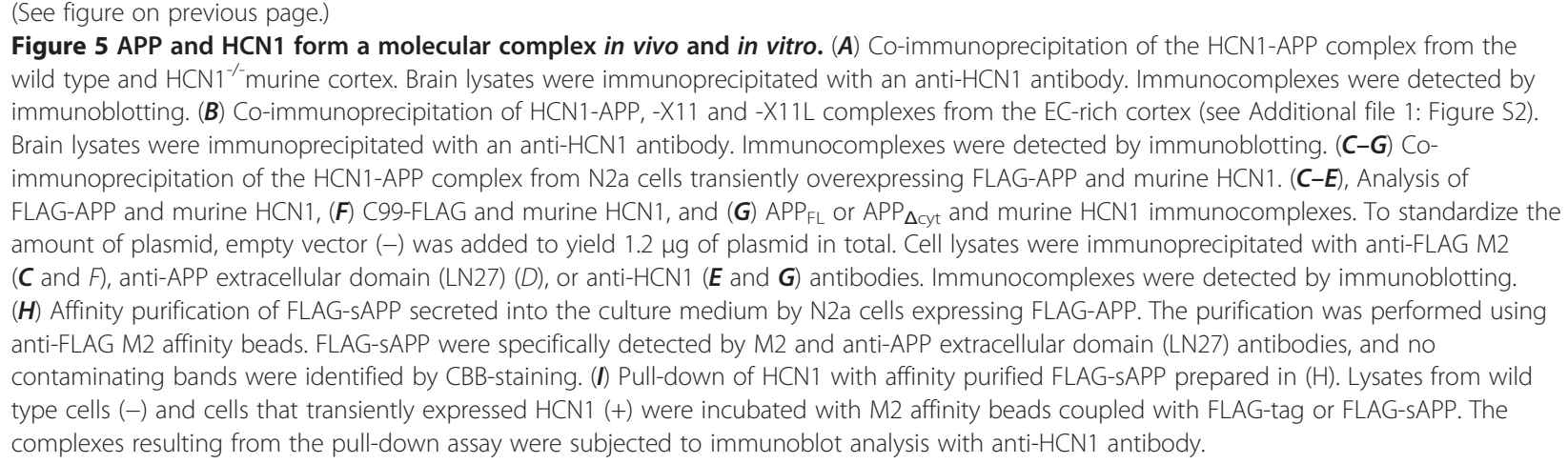

assay was performed. The anti-FLAG M2 antibody immunoprecipitated HCN1 along with FLAG-APP (Figure 5C). An anti-hAPP extracellular domain antibody (LN27) also recovered $\mathrm{HCN} 1$ (Figure 5D), and anti-HCN1 antibody recovered FLAG-APP (Figure 5E).

APP is a type I transmembrane protein composed of a large extracellular (luminal) domain of 596 amino acids and a small intracellular domain of 47 amino acids. On the other hand, HCN1 is six-transmembrane protein with short extracellular sequences between transmembrane regions one and two, three and four, and five and six; and long intracellular domains within the aminoand carboxyl-terminal regions of the protein. To determine the region of APP that binds to $\mathrm{HCN} 1$, we performed co-immunoprecipitation assays using APP deletion mutants (C99-FLAG, which largely lacks the extracellular domain of APP and in which FLAG is fused to the carboxyl terminal region of APP; and $\mathrm{APP}_{\Delta \text { cyt }}$, which lacks the 43- amino acid carboxyl terminal region of APP) (Figure 5F, G). The results of this assay indicated that $\mathrm{HCN} 1$ was not co-immunoprecipitated with C99-FLAG (Figure 5F), whereas $\mathrm{APP}_{\Delta \text { cyt }}$ was coimmunoprecipitated with HCN1 (Figure 5G).

Next, we performed an in vitro pull-down assay with FLAG-soluble APP (FLAG-sAPP, consisting of the extracellular domain of APP cleaved at the $\alpha$ - and/or $\beta$-cleavage sites). FLAG-sAPP was purified with affinity beads (antiFLAG M2 affinity gel) from the culture medium of N2a cells expressing FLAG-APP (Figure $5 \mathrm{H}$ ) and then incubated with lysates of N2a cells that expressed HCN1. HCN1 bound to FLAG-sAPP, but not to FLAG-tag alone (Figure 5I). Taken together, the results shown in Figure 5 indicate that HCN1 associates with APP through its extracellular (luminal) domain.

Hence, HCN1 apparently interacts with the extracellular domain of APP (Figure 5) and with both X11 and X11L in the cytoplasm (Figure $3 \mathrm{H}-\mathrm{K}$, Figure 5B). This suggests that the HCN1 channel might form a ternary complex with APP and either X11 or X11L to regulate $A \beta$ generation. However, the detailed molecular regulation of complex formation remains to be determined.

\section{Age- and AD state-dependent HCN disruption in the temporal cortex (superior temporal gyrus) of cynomolgus monkeys and sporadic AD patients}

Advanced age is the greatest risk factor for AD. To examine the relationship between aging and $\mathrm{HCN} 1$ levels, we quantified the amount of $\mathrm{HCN} 1, \mathrm{~A} \beta, \mathrm{APP}$, and actin in freshly frozen brain tissues (superior temporal gyrus) from cynomolgus monkeys of various ages (Figure 6A and Additional file 1: Figure S6). Senile plaques and neurofibrillary tangles spontaneously appear in the brains of cynomolgus monkeys with advancing age $[32,33]$, and the amino acid sequence of $A \beta$ in cynomolgus monkeys is identical to that in humans [34]. Thus, we hypothesized that the cynomolgus monkey would be a useful animal model for the investigating the relationship between aging and AD pathology. Significant negative correlations were found between HCN1 levels and age $(\mathrm{n}=39, \mathrm{r}=-0.5363, p=0.0004)$ (Figure 6A, left), between HCN1 and APP levels $(\mathrm{n}=39, \mathrm{r}=-0.3796$, $p=0.0086$ ) (Additional file 1: Figure S6B), between HCN1 and TBS-insoluble A $\beta 40$ levels $(\mathrm{n}=39, \mathrm{r}=-0.2878$, $p=0.0421$ ) (Additional file 1: Figure S6C and D), and between HCN1 and Tris buffered saline (TBS)-insoluble A 342 levels $(n=39, r=-0.2913, p=0.0401)$ (Additional file 1: Figure S6E and F). A significant positive correlation was found between age and APP level $(n=39, r=0.8156$, $p<0.0001$ ) (Additional file 1: Figure S6A), and a significant weak-positive correlation was found between APP and TBS-insoluble A $\beta 42$ levels $(\mathrm{n}=39, \mathrm{r}=0.3714, p=0.0236)$ (Additional file 1: Figure $\mathrm{S} 6 \mathrm{H}$ ). However, no correlation was found between age and actin level $(\mathrm{n}=39, \mathrm{r}=-0.1981$, $p=0.2266$ ) (Figure 6A, right) or between APP and TBS-insoluble A 340 levels $(\mathrm{n}=39, \mathrm{r}=0.2993, p=0.072)$ (Additional file 1: Figure S6G).

Finally, we examined the possibility of altered HCN1 levels in human AD brain specimens obtained at autopsy 


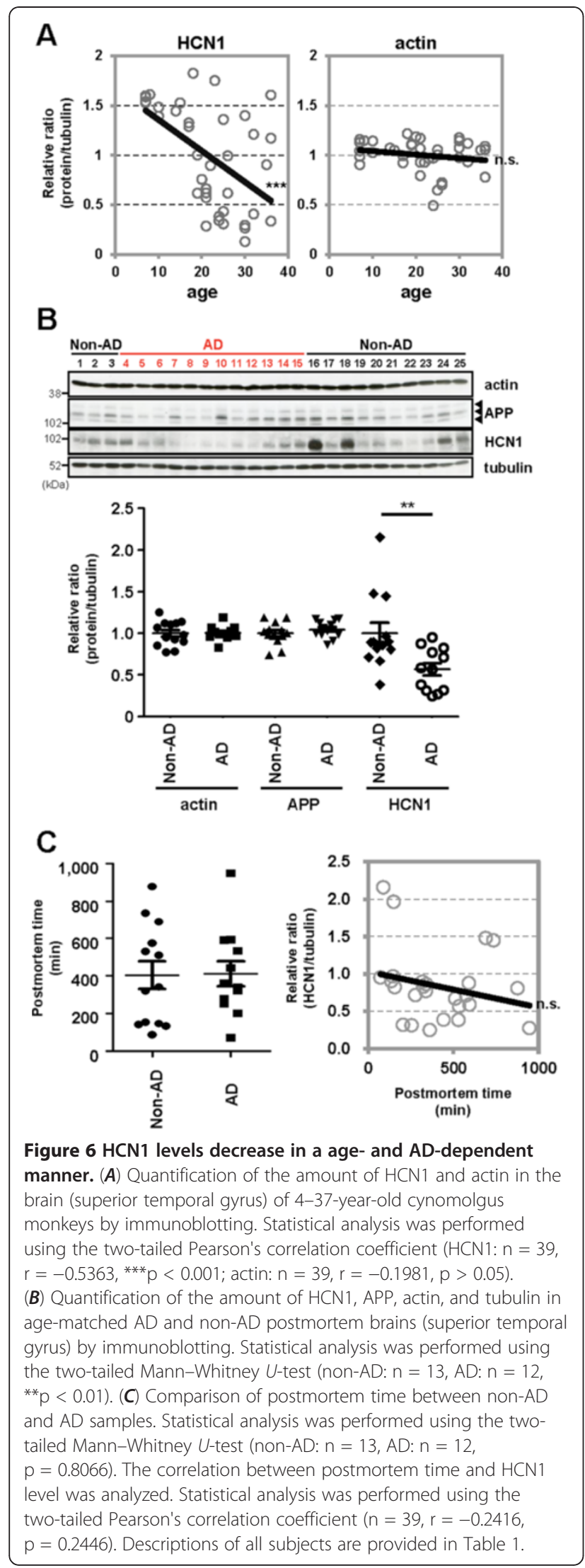

(Figure 6B and Table 1). The postmortem time was not significantly different for the $A D$ and non- $A D$ brain samples used in this study (non-AD: $\mathrm{n}=13, \mathrm{AD}: \mathrm{n}=12$, $p=0.8066$ ), and no significant decrease in HCN1 levels related to postmortem time was observed $(\mathrm{n}=25$, $\mathrm{r}=-0.2416, p=0.2446$ ) (Figure $6 \mathrm{C}$ and Table 1). Of great relevance to this study, the amount of $\mathrm{HCN} 1$ was significantly reduced in $\mathrm{AD}$ brains (superior temporal gyrus) compared with that in age-matched control brains (non$\mathrm{AD}: \mathrm{n}=13, \mathrm{AD}: \mathrm{n}=12, p=0.0083$ ), while the levels of APP and actin were not significantly altered (Figure 6B and Table 1). These results suggest that the reduction in HCN1 expression that occurs with age (Figure 6A) may be involved in the aggravation of the pathology of $\mathrm{AD}$.

\section{Discussion}

X11 and X11L are well-characterized neural adaptor proteins that regulate the trafficking and metabolism of APP [14]. Many reports indicate that X11s bind to APP and suppress $A \beta$ generation in vitro and in vivo [14-22]. Furthermore, X11s are thought to mediate a number of cellular functions through their association with various proteins [35]. This report showed that mutant mice lacking both X11 and X11L present with dysfunctional HCN1 channel activity and epileptic seizures. Notably, AD patients are also at increased risk of epileptic seizures. Furthermore, mutant mice lacking $\mathrm{HCN} 1$ demonstrated increased generation of $A \beta$, which is a causative factor for the development of $\mathrm{AD}$.

The incidence of $\mathrm{AD}$ dramatically increases with age. We found that the amount of HCN1 decreased with both aging and in AD. The dysfunction of HCN1 that occurs over time may, thus, be a trigger for epileptic seizures and the pathogenic generation of $\mathrm{A} \beta$ in $\mathrm{AD}$.

Several converging studies corroborate the premise that $\mathrm{HCN}$ channel activity is closely related to epileptogenesis [11]. For example, HCN1 expression is significantly reduced in the EC after temporal lobe epilepsy [36,37]. Furthermore, $\mathrm{HCN} 1$ channel plasticity in cortical neurons is similar in multiple epileptic animal models [38-43]. Moreover, kainic acid-induced seizure susceptibility is increased in $\mathrm{HCN}^{-1-}$ mice [27], and $\mathrm{HCN} 2$-deficient mice exhibit spontaneous absence seizures [26].

$\mathrm{HCN} 1^{-/-}$mice show a significantly higher number of negative resting membrane potentials and a significantly higher input resistance measured from responses to either negative or positive current steps [28]. As such, seizure susceptibility is increased in $\mathrm{HCN}^{-1-}$ mice [27], indicating that loss of the $\mathrm{HCN} 1$ subunit enhances neuronal excitability, which can increase $A \beta$ generation [8-10]. These observations suggest that enhanced $A \beta$ generation in $\mathrm{HCN}^{-1-}$ mice results from neuronal hyper-excitability, which is in turn caused by ablation of the HCN1 gene. 
Table 1 Summary of subject information presented in Figure 6B and C

\begin{tabular}{|c|c|c|c|c|c|c|c|c|c|}
\hline \multirow{2}{*}{$\begin{array}{l}\text { Sample } \\
\text { no. }\end{array}$} & \multirow[t]{2}{*}{ Subject } & \multirow[t]{2}{*}{ Age } & \multirow[t]{2}{*}{ Sex } & \multirow{2}{*}{$\begin{array}{l}\text { Post } \\
\text { mortem } \\
\text { time } \\
\text { (min) }\end{array}$} & \multirow{2}{*}{$\begin{array}{l}\text { Braak } \\
\text { stage }\end{array}$} & \multirow[t]{2}{*}{ Seizure } & \multicolumn{3}{|c|}{ Relative ratio (protein/tubulin) } \\
\hline & & & & & & & Actin & APP & HCN1 \\
\hline 1 & Normal & 84 & $\mathrm{~F}$ & 877 & 1 & - & 0.929 & 1.192 & 0.809 \\
\hline 2 & Normal & 88 & $\mathrm{~F}$ & 144 & 1 & - & 0.856 & 1.046 & 0.859 \\
\hline 3 & Normal & 70 & M & 340 & 0.5 & - & 0.955 & 1.189 & 0.859 \\
\hline 4 & $A D$ & 84 & M & 71 & 4 & - & 0.950 & 1.171 & 0.952 \\
\hline 5 & $A D$ & 70 & M & 276 & 4 & - & 0.829 & 0.986 & 0.716 \\
\hline 6 & $A D$ & 74 & M & 322 & 5 & - & 0.961 & 0.990 & 0.827 \\
\hline 7 & $A D$ & 75 & M & 594 & 6 & - & 1.069 & 1.176 & 0.589 \\
\hline 8 & $A D$ & 76 & M & 947 & 6 & + & 1.190 & 1.167 & 0.273 \\
\hline 9 & $A D$ & 79 & $\mathrm{~F}$ & 203 & 5 & - & 1.019 & 0.913 & 0.317 \\
\hline 10 & $A D$ & 81 & M & 360 & 6 & - & 0.971 & 0.862 & 0.247 \\
\hline 11 & $A D$ & 81 & F & 442 & 5 & - & 0.971 & 0.862 & 0.385 \\
\hline 12 & $A D$ & 82 & $\mathrm{~F}$ & 254 & 6 & - & 0.988 & 1.029 & 0.313 \\
\hline 13 & $A D$ & 82 & $\mathrm{~F}$ & 533 & 5 & - & 0.988 & 1.001 & 0.566 \\
\hline 14 & $A D$ & 82 & $\mathrm{~F}$ & 338 & 4 & - & 1.028 & 1.063 & 0.770 \\
\hline 15 & $A D$ & 84 & M & 590 & 5 & - & 1.071 & 1.128 & 0.876 \\
\hline 16 & Normal & 78 & $\mathrm{~F}$ & 87 & 2 & - & 1.108 & 1.138 & 2.153 \\
\hline 17 & Normal & 81 & M & 134 & 1 & - & 1.122 & 0.971 & 0.902 \\
\hline 18 & Normal & 82 & $\mathrm{~F}$ & 148 & 1 & - & 1.178 & 1.109 & 1.963 \\
\hline 19 & Normal & 82 & $\mathrm{~F}$ & 155 & 2 & - & 1.141 & 1.026 & 0.821 \\
\hline 20 & Normal & 80 & M & 317 & 2 & - & 1.254 & 1.037 & 0.893 \\
\hline 21 & Normal & 80 & M & 510 & 2 & - & 1.071 & 0.778 & 0.669 \\
\hline 22 & Normal & 82 & M & 530 & 1 & - & 0.979 & 0.916 & 0.384 \\
\hline 23 & Normal & 78 & M & 575 & 1 & - & 0.905 & 1.007 & 0.713 \\
\hline 24 & Normal & 78 & M & 690 & 1 & - & 0.784 & 0.986 & 1.479 \\
\hline 25 & Normal & 82 & $M$ & 736 & 1 & - & 0.774 & 0.743 & 1.448 \\
\hline
\end{tabular}

Postmortem brain samples were obtained from the Brain Bank for Aging Research, Tokyo Metropolitan Institute of Gerontology. Experimental procedures were approved by the appropriate ethical boards at each institute. Autopsies were performed with written informed consent from the patients or their relatives. The clinical diagnosis of AD was based on two major criteria: the Diagnostic and Statistical Manual of Mental Disorders: 4th Edition (DSM-IV) and the National Institute of Neurological and Communicational Disorders and Stroke-Alzheimer's Disease and Related Disorders Association (NINCDS-ADRDA). The neuropathological diagnosis of $A D$ was made using Consortium to Establish a Registry for Alzheimer's Disease criteria (average age at death, $79.2 \pm 4.4$ years). Control brains were obtained from age-matched individuals with no history of neurological or psychiatric illness (average age at death, $80.4 \pm 4.2$ years). Subjects, age, gender, postmortem time, Braak stage, seizure history, and relative protein/tubulin ratios are indicated.

On the other hand, the present study showed that HCN1 physically associated with APP through the extracellular domain of APP. Therefore, HCN1-mediated regulation of $\mathrm{A} \beta$ generation may depend on a molecular linkage between HCN1 and APP and not simply on alterations in neuronal excitability. However, the molecular mechanism by which $\mathrm{HCN} 1$ potentially links epileptic seizures to $A \beta$ generation in $A D$ remains to be elucidated.

Our results suggest that ablation of X11/X11L induces aberrant HCN1 distribution and function along with epilepsy. Although the molecular mechanism by which $\mathrm{X} 11$ s regulates $\mathrm{HCN}$ channel activity also remains unclear, X11s are known to modulate intracellular trafficking of membrane proteins. For example, X11s interact with certain proteins implicated in traffic and transport, such as Arfs, Rab6, and KIF17 [29,44,45]. Furthermore, X11s bind to vesicular cargo proteins, such as APP and alcadein $[16,46,47]$ and regulate the intracellular distribution of APP $[21,30]$. We hypothesize that X11 and X11L similarly influence the trafficking and/or intracellular localization of HCN1. We further hypothesize that the mislocalization of $\mathrm{HCN} 1$ observed in $\mathrm{X}_{1} 1^{-1-}$ / $\mathrm{X}_{11 \mathrm{~L}^{-1-}}$ mice (Additional file 1: Figure S4) may cause aberrant excitatory neuronal activities, resulting in epileptic seizures.

In conclusion, this study indicates that $\mathrm{HCN} 1$ may play an important role in the regulation of neuronal 
activity, along with $A \beta$ generation in the hippocampal formation. However, we cannot rule out the possibility that additional ion channels (e.g., M-channels, Kir-channels, and sodium leak channels) also participate in the regulation of APP metabolism. Taken together, the current observations may provide new insights into the mechanisms underlying the linkage between epileptic seizures and $A \beta$ generation in $\mathrm{AD}$.

\section{Methods}

\section{Animals and human non-AD and AD brain samples}

All animal studies were conducted in compliance with the guidelines of the Animal Studies Committees of Hokkaido University (Sapporo, Japan), Shiga University (Shiga, Japan), and the National Institute of Biomedical Innovation (Osaka, Japan). Mice were maintained under a 12-h light/12-h dark cycle (lights on, 7:00 A.M.-7:00 P.M.), and provided with food and water ad libitum. $\mathrm{X} 11^{-/-} / \mathrm{X} 11 \mathrm{~L}^{+/+}, \mathrm{X} 11^{+/+} / \mathrm{X} 11 \mathrm{~L}^{-/-}$, and $\mathrm{X} 11^{-/-} / \mathrm{X}_{11 L^{-/-}}$mice have already been described $[20,21]$. $\mathrm{HCN}^{-1-}$ mice (stock number 005034) were purchased from The Jackson Laboratory (Bar Harbor, Maine). Male mice were used for all experiments.

Brain samples containing the superior temporal gyrus of cynomolgus monkeys (Macaca fascicularis) were obtained from Shiga University of Medical Science and the National Institute of Biomedical Innovation. The monkeys were housed in individual cages prior to the experiment and were maintained according to institutional guidelines for experimental animal welfare. Human brain samples containing the superior temporal gyrus (Broadmann area 22) were obtained from the Brain Bank for Aging Research, the Tokyo Metropolitan Institute of Gerontology (Itabashi, Tokyo, Japan). Human temporal cortical specimens for the quantification of proteins were obtained from brains that were removed, processed, and stored at $-80^{\circ} \mathrm{C}$ within $16 \mathrm{~h}$ postmortem at the Brain Bank at Tokyo Metropolitan Institute of Gerontology. (Patients were placed in a cold $\left(4^{\circ} \mathrm{C}\right)$ room within $2 \mathrm{~h}$ of death.) For all brains registered at the bank, written informed consent for their use for medical research was obtained from the patient prior to death or from the patient's family. Brain specimens were collected from Broadmann area 22 (superior temporal gyrus) for $12 \mathrm{AD}$ patients $(79.2 \pm 4.4$ years of age) and 13 control patients $(80.4 \pm 4.2$ years of age) [48]. Detailed descriptions of all subjects, including the relative protein/ tubulin ratio for each individual, are shown in Table 1.

\section{Antibodies}

Polyclonal rabbit anti-HCN1 antibody [25] and polyclonal rabbit anti-X11 UT153 antibody [21] have already been described. Monoclonal mouse anti-tubulin DM1A antibody and polyclonal rabbit anti-c-Fos, rabbit antiEgr-1, and goat anti-HCN1 antibodies (sc-19706) were purchased from Santa Cruz Biotechnology (Santa Cruz, CA, USA). Characterization and demonstration of the antigen-specificity of the goat anti-HCN1 antibody (sc-19706) is shown in Additional file 1: Figure S7. Monoclonal mouse anti-X11L/mint2 and anti-PSD95 antibodies were purchased from BD Transduction Laboratories (Lexington, KY, USA). Anti-actin antibody and the anti-HCN1 antibody, AB5884, were purchased from Millipore (Billerica, MA, USA). Anti-FLAG M2 and polyclonal rabbit anti-APP cytoplasmic domain (N-terminus) antibodies were purchased from Sigma-Aldrich (St. Louis, MO, USA), and the anti-human APP extracellular domain antibody (LN27) was purchased from Zymed (San Francisco, CA, USA). Anti-FLAG M2 affinity gel and FLAG peptide were purchased from Sigma-Aldrich.

\section{Plasmid construction}

Human APP695 (hAPP695) and FLAG-APP695 cDNA were inserted into the pcDNA3 plasmid at the HindIII/ XbaI restriction sites to produce pcDNA3-hAPP695 and pcDNA3-FLAG-hAPP695 [46]. The cDNA constructs

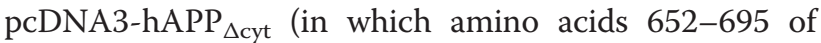
hAPP695 are deleted) and pcDNA3.1-C99-FLAG (in which the signal sequence of hAPP is inserted into the 5', region of C99) were generated by PCR using pcDNA3hAPP695 as the template. The generated fragments were ligated into pcDNA3-hAPP695 and pcDNA3.1-FLAG at the BamHI/XbaI restriction site and the HindIII/XbaI restriction site, respectively. The pCI-murine $\mathrm{HCN} 1$ vector was a kind gift from Dr. Takahiro M. Ishii [49].

\section{Immunohistochemistry}

Murine brain tissue sections were prepared and incubated with primary antibodies as described [21]. The sections were further incubated with goat anti-rabbit IgG antibodies conjugated to biotin (Vector Laboratories, Burlingame, CA, USA), followed by the ABC complex. Peroxidase activity was revealed using diaminobenzidine as the chromogen. Alternatively, sections were incubated with donkey anti-mouse IgG coupled with Alexa Fluor 488, donkey anti-rabbit IgG coupled with Cy3, or donkey anti-goat IgG coupled with Alexa Fluor 633 in phosphate buffered saline (PBS) containing $3 \%$ bovine serum albumin (BSA) for $2 \mathrm{~h}$ at room temperature. Sections were mounted onto slides with Shandon Immu-Mount (Thermo, Pittsburgh, PA, USA) and viewed under a BZ-9000 microscope (Keyence, Woodcliff Lake, NJ, USA).

\section{Immunoblotting and co-immunoprecipitation analysis}

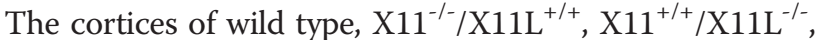
$\mathrm{X}_{1} 1^{-1-} / \mathrm{X}_{11 \mathrm{~L}^{-/-}}, \mathrm{HCN1}^{+/-}$, and $\mathrm{HCN1}^{-/-}$mice, and cynomolgus monkey brains (superior temporal gyrus) and human post-mortem brains (superior temporal gyrus) were homogenized in eight volumes of radioimmune 
precipitation assay buffer containing $0.5 \%(\mathrm{w} / \mathrm{v})$ sodium dodecyl sulfate (SDS) and a protease inhibitor mixture (5 $\mu \mathrm{g} / \mathrm{ml}$ chymostatin, $5 \mu \mathrm{g} / \mathrm{ml}$ leupeptin, and $5 \mu \mathrm{g} / \mathrm{ml}$ pepstatin). The homogenates were lysed by sonication on ice and centrifuged at $20,000 \times \mathrm{g}$ for $10 \mathrm{~min}$ at $4{ }^{\circ} \mathrm{C}$. The resulting supernatants were used for immunoblot analysis. Proteins $(10 \mu \mathrm{g}$ per lysate) were separated via SDS $(\mathrm{w} / \mathrm{v})$ polyacrylamide gel electrophoresis (SDS-PAGE) on $7.5 \%(\mathrm{w} / \mathrm{v})$ polyacrylamide gels.

The cortex (from one mouse) and EC-rich region (from five mice) from wild type and gene-null mice were homogenized in eight volumes of HBS-T lysis buffer (10 mM HEPES [pH 7.6] containing $150 \mathrm{mM} \mathrm{NaCl}, 5 \mathrm{mM}$ EDTA, $0.5 \%[\mathrm{v} / \mathrm{v}]$ Triton X-100, $5 \mu \mathrm{g} / \mathrm{ml}$ chymostatin, $5 \mu \mathrm{g} / \mathrm{ml}$ leupeptin, and $5 \mu \mathrm{g} / \mathrm{ml}$ pepstatin A). Homogenates were then centrifuged at $20,000 \times \mathrm{g}$ for $10 \mathrm{~min}$ at $4^{\circ} \mathrm{C}$. $\mathrm{N} 2 \mathrm{a}$ cells $\left(\sim 1 \times 10^{6}\right)$ were transiently transfected with $0.8 \mu \mathrm{g}$ pcDNA3-FLAG-hAPP695, pcDNA3-hAPP695, pcDNA3$\mathrm{hAPP}_{\Delta \mathrm{cyt}}$, or pcDNA3.1-C99-FLAG and $0.4 \mu \mathrm{g}$ of pCI-murine HCN1 using Lipofectamine 2000 (Invitrogen) and cultured for $24 \mathrm{~h}$ in medium (DMEM) containing $10 \%(\mathrm{v} / \mathrm{v})$ fetal bovine serum (FBS). Cells were harvested, lysed in lysis buffer (PBS containing 1.0\% [v/v] Triton X-100, $5 \mu \mathrm{g} / \mathrm{ml}$ chymostatin, $5 \mu \mathrm{g} / \mathrm{ml}$ leupeptin, and $5 \mu \mathrm{g} / \mathrm{ml}$ pepstatin A), and centrifuged for $5 \mathrm{~min}$ at $4^{\circ} \mathrm{C}$. The resulting supernatants were incubated with antiFLAG M2, anti-hAPP extracellular domain (LN27), anti$\mathrm{HCN} 1$, anti-X11, or anti-X11L/Mint2 antibody at $4^{\circ} \mathrm{C}$ for 2 h. Each immunocomplex was recovered with Dynabeads ${ }^{\circledR}$ Protein $\mathrm{G}$ (Invitrogen) and washed three times with lysis buffer. The proteins were separated on $7.5 \%(\mathrm{w} / \mathrm{v})$ polyacrylamide gels, transferred onto nitrocellulose membranes, and analyzed by immunoblotting with the indicated antibodies. The immunoreactants were detected using the ECL plus ${ }^{\mathrm{TM}}$ detection system (GE Healthcare, Houston, TX, USA) and quantified using a Versa Doc model 3000 (Bio-Rad, Hercules, CA, USA).

\footnotetext{
Affinity purification of FLAG-SAPP from N2a conditioned medium and immunoprecipitation of APP-HCN1 complex N2a cells $\left(\sim 8.8 \times 10^{6}\right)$ were transiently transfected with $5 \mu \mathrm{g}$ pcDNA3-FLAG-hAPP695 using Lipofectamine 2000 (Invitrogen) and cultured for $24 \mathrm{~h}$ in $8 \mathrm{~mL}$ of medium (DMEM) containing 10\% (v/v) FBS. FLAG-sAPP was collected from the conditioned culture medium by using $50 \mu \mathrm{L}$ of anti-FLAG M2 affinity gel. The collected FLAGSAPP that was bound to the gel was washed twice with wash buffer I (20 mM Tris- $\mathrm{HCl}$ [pH 8.0], $1 \mathrm{M} \mathrm{NaCl}$, and $0.1 \%$ Triton X-100) and twice with wash buffer II (50 mM Tris-HCl [pH8.0], $150 \mathrm{mM} \mathrm{NaCl}, 1 \%$ Triton X-100, 0.05\% SDS, and $5 \mathrm{mM}$ EDTA). Collected FLAG-sAPP was then eluted from the affinity gel with $20 \mu \mathrm{g}$ FLAG-peptide and subjected to immunoblotting and Coomassie brilliant blue $(\mathrm{CBB})$ staining to ascertain the degree of purification.
}

FLAG-sAPP or FLAG-peptide coupled to anti-FLAG M2 affinity beads were then incubated for $2 \mathrm{~h}$ at $4^{\circ} \mathrm{C}$ with $\mathrm{HBS}$-T-soluble lysates derived from wild type $\mathrm{N} 2 \mathrm{a}$ cells or N2a cells transiently overexpressing HCN1. The beads were washed three times with HBS-T lysis buffer. The proteins bound to the beads were separated on $7.5 \%$ $(\mathrm{w} / \mathrm{v})$ polyacrylamide gels, transferred onto membranes, and analyzed by immunoblotting with the indicated antibodies. The immunoreactants were detected using the ECL plus ${ }^{\mathrm{Tm}}$ detection system (GE Healthcare) and quantified using a Versa Doc model 3000 (Bio-Rad).

\section{Quantification of $A \beta 40$ and $A \beta 42$}

Endogenous murine $A \beta$ was measured as described previously [21] using cortices dissected from 4-month-old mice. Murine $A \beta 40$ and $A \beta 42$ were measured using a sandwich ELISA (sELISA) system (mouse/rat A $\beta 40$ and A $\beta 42$ assay kit, Immuno-Biological Laboratories (IBL), Fujioka, Japan). N2a cells $\left(\sim 2 \times 10^{5}\right)$ were transiently transfected with $0.2 \mu \mathrm{g}$ pcDNA3-FLAG-hAPP695 and $0.1 \mu \mathrm{g}$ pCI-murine HCN1 using Lipofectamine 2000 (Invitrogen) and cultured in medium (DMEM) containing $10 \%(\mathrm{v} / \mathrm{v})$ FBS. After $24 \mathrm{~h}$, cells were incubated in fresh medium for an additional $4 \mathrm{~h}$ with or without $10 \mu \mathrm{M}$ ZD7288 (Tocris Bioscience, Bristol, UK). Human A $\beta 40$ (hA 340$)$ and $h A \beta 42$ secreted into the culture medium during the 4-h incubation were quantified using the sELISA system.

\section{Electroencephalogram recording}

To obtain free-moving cortical electrocorticogram recordings, recording and reference electrodes were screwed onto the skull over the temporal (anterior $=-3.1 \mathrm{~mm}$, lateral $=$ $2.5 \mathrm{~mm}$, relative to bregma) and occipital regions of the murine brain. Recordings were continuously made using a cortical electroencephalogram linked to a telemetry system (Unimec, Usmate Velate, Italy) throughout the experiment [50].

\section{Ih current recording}

All experiments were performed in a blinded manner. Mice (12-14 weeks old) were anesthetized with halothane (Takeda Chemical Industries) and then sacrificed by decapitation. The brain was rapidly removed and immediately placed in a cold $\left(4^{\circ} \mathrm{C}\right)$ cutting solution, which contained $234 \mathrm{mM}$ sucrose, $2.5 \mathrm{mM} \mathrm{KCl}, 1.1 \mathrm{mM}$ $\mathrm{NaH}_{2} \mathrm{PO}_{4}, 10 \mathrm{mM} \mathrm{MgSO}, 26 \mathrm{mM} \mathrm{NaHCO}, 12 \mathrm{mM}$ glucose, and $0.5 \mathrm{mM} \mathrm{CaCl}$. Horizontal slices $(300 \mu \mathrm{m}$ thick), which included the EC and the hippocampus, were prepared using a vibratome (VT1000S, Leica, Nussloch, Germany). During recording, individual slices were transferred to a submerged recording chamber and continuously perfused with artificial cerebrospinal fluid (ACSF) maintained at $30-32^{\circ} \mathrm{C}$. The ACSF contained $125 \mathrm{mM}$ 
$\mathrm{NaCl}, 2.5 \mathrm{mM} \mathrm{KCl}, 1.1 \mathrm{mM} \mathrm{NaH}_{2} \mathrm{PO}_{4}, 1.0 \mathrm{mM} \mathrm{MgSO}_{4}$, $26 \mathrm{mM} \mathrm{NaHCO}_{3}, 12 \mathrm{mM}$ glucose, and $2.0 \mathrm{mM} \mathrm{CaCl}_{2}$ and was saturated with $95 \% \mathrm{O}_{2}$ and $5 \% \mathrm{CO}_{2}$. Whole-cell patch-clamp recordings were obtained from principal excitatory cells in layer II of the EC. The patch pipettes were filled with an intracellular solution containing $30 \mathrm{mM}$ K-methanesulfonate, $6 \mathrm{mM} \mathrm{NaCl}, 0.2 \mathrm{mM}$ EGTA, $10 \mathrm{mM}$ HEPES, $4 \mathrm{mM} \mathrm{Mg-ATP,} 0.3 \mathrm{mM} \mathrm{Na}$-GTP, and $10 \mathrm{mM}$ phosphocreatine-Tris ( $\mathrm{pH}$ 7.3). In layer II cells of the EC, the hyperpolarization-induced and "slowly-activating" inward currents in the voltage-clamp mode mainly consisted of Ih currents [51]. When Ih currents were studied in the voltage-clamp mode, membrane potentials were first held at $-65 \mathrm{mV}$, and then voltage steps with a duration of $7 \mathrm{~s}$ were applied from $-55 \mathrm{mV}$ to $-125 \mathrm{mV}$ (10 $\mathrm{mV}$ increments), after which the holding potentials were allowed to return to $-65 \mathrm{mV}$ to obtain the tail currents. The amplitudes of the tail currents at $50 \mathrm{~ms}$ after the end of the final voltage step were analyzed to obtain the Ih currents. In all electrophysiological analyses, pooled data were represented as the mean \pm SEM.

\section{Statistical analysis}

Statistical analyses were performed using a two-tailed Mann-Whitney $U$-test, a one-way analysis of variance followed by Tukey's multiple comparison test, or the two-tailed Pearson's correlation coefficient. All analyses were conducted with GraphPad Prism 5 software.

\section{Additional files}

\section{Additional file 1: Figure S1. Simultaneous recording of}

electrocorticogram in epilepsy model mice and corresponding movie. A representative electrocorticogram recorded during the interictal period in 13-week-old $\times 11^{-1-} / X_{11 L^{-1}}$ mice $(n=4)$ is shown. The underlined region indicates the time frame of the corresponding movie (Movie S3).

Figure S2. Individual data of Ih currents density in entorhinal cortex layer II neurons of wild-type and X11s-null mice. (A) Indicidual data of Ih current density. Blue indicate the data of mouse $\# 1$ and red indicate mouse \#2. (B) Mean, SD, SEM, and count number of A. P Value of Student's t-test (\#1 vs \#2) shown in bottom line. (C) Distribution and average of current density of $A$. Closed symbols indicate the data of mouse \#1 and opened symbols indicate mouse \#2 (mean \pm SEM). Figure S3. HCN1 levels in the EC-rich region of the brains of $X 11^{+/+} / \mathrm{X} 11 \mathrm{~L}$ + and $X 11$ s mutant mice. $(\boldsymbol{A})$ Isolation of the EC-rich region from a horizontal slice (300 $\mu \mathrm{m}$ thick) of murine brain. Brain slices from 13-weekold $\mathrm{X} 11^{+/+} / \mathrm{X} 11 \mathrm{~L}^{+/+}, \mathrm{X} 11^{+/+} / \mathrm{X} 11 \mathrm{~L}^{-/}, \mathrm{X} 11^{-/} / \mathrm{X} 11 \mathrm{~L}^{+/+}$, and $\mathrm{X} 11^{-/ /} / \mathrm{X} 11 \mathrm{~L}^{-/}$mice were prepared in ice-cold PBS using a vibratome (VT1200S; Leica) (left panel). The EC-rich region (EC) was separated from each slice as indicated (right panel). ( $\boldsymbol{B}, \boldsymbol{C})$ Quantification of $\mathrm{HCN} 1$ in the EC-rich region. Horizontal slices were homogenized in eight volumes of radioimmune precipitation assay buffer containing 0.5\% (w/v) SDS and a protease inhibitor mixture $(5 \mu \mathrm{g} / \mathrm{ml}$ chymostatin, $5 \mu \mathrm{g} / \mathrm{ml}$ leupeptin, and $5 \mathrm{\mu g} / \mathrm{ml}$ pepstatin), subjected to sonication on ice, and centrifuged at $20,000 \times \mathrm{g}$ for $10 \mathrm{~min}$ at $4^{\circ} \mathrm{C}$. (B) The resulting supernatants (each containing $10 \mu \mathrm{g}$ protein) were analyzed by SDS-PAGE on $7.5 \%(\mathrm{~W} / \mathrm{v})$ polyacrylamide gels, followed by immunoblotting with anti-HCN1, anti$X 11$, anti-X11L, and anti-tubulin antibodies $(n=4)$. (C) The HCN1 level was normalized to the tubulin level to give the relative HCN1/tubulin ratio for each genotype (mean $\pm S E M, n=4)$. Figure S4. Altered distribution of the $\mathrm{HCN}$ channel in $\mathrm{X} 11^{-/} / \mathrm{X} 11 \mathrm{~L}^{-/}$mice. $(\boldsymbol{A})$ Low-power images of horizontal brain sections from 13-week-old wild type

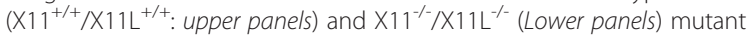
mice were immunostained with an anti-HCN1 antibody $(n=3)$. Scale bar, $300 \mu \mathrm{m}$. (B) Representative high-resolution images of horizontal brain sections from 13-week-old $X 11^{+/+} / \mathrm{X} 11 \mathrm{~L}^{+/+}(a, c)$ and $\mathrm{X} 11^{-/-} / \mathrm{X} 11 \mathrm{~L}^{-/-}(b, d)$ mice were subjected to immunostaining with an anti-HCN1 antibody $(a, b)$ and Nissl stain $(c, d)$. (C) Quantitative analysis of HCN1 immunoreactivity in the EC of 13 -week-old wild type $\left(\mathrm{X}_{11^{+/+}} / \mathrm{X} 11 \mathrm{~L}^{+/+}\right)$ and $\mathrm{X} 11^{-/} / \mathrm{X} 11 \mathrm{~L}^{-1-}$ mutant mice. The intensity of the HCN1 immunoreactivity in the areas enclosed by the open boxes in $A$ was measured using NIH Image J software. Scale bar, $50 \mu \mathrm{m}$.

Figure S5. Complex formation of HCN1 with APP in N2a cells treated with ZD7288. FLAG-APP and HCN1 were transiently overexpressed in N2a cells $\left(\sim 1 \times 10^{6}\right)$ with $(+)$ or without $(-) 10 \mu \mathrm{M}$ ZD7288. To standardize the amount of plasmid transfected into the cells, an empty vector (-) was added to yield $1.2 \mu \mathrm{g}$ of plasmid in total. The cell lysates were subjected to immunoprecipitation with anti-FLAG M2 antibody. Immunocomplexes were detected by immunoblotting with anti-HCN1 and anti-FLAG antibodies. Figure S6. Covariance analysis of various protein levels in the brain of cynomolgus monkeys. (A-H) Levels of HCN1, APP, A $\beta 40$, and $A \beta 42$ in the brain (superior temporal gyrus) of 4-37-year-old cynomolgus monkeys were quantified by immunoblotting and sELISA assay. Protein levels were normalized to tubulin levels or to tissue weight to give the relative protein/tubulin ratio for immunoblotting and the relative protein/ tissue weight ratio for SELISA. (A) Correlation between age and APP level ( $\left.n=39, r=0.8156,{ }^{* * * *} p<0.0001\right)$. (B) Correlation between HCN1 and APP levels $\left(n=39, r=-0.3796,{ }^{* *} p=0.0086\right)$. (C, D) Correlation between HCN1 and AB40 levels $\left(n=39, r=-0.2878,{ }^{*} p=0.0421\right)$. An enlarged view of $(C)$ in the 0 to $1,000 \mathrm{f} \mathrm{mol} / \mathrm{mg}$ tissue range is shown in (D) $(E, F)$ Correlation between HCN1 and Aß42 levels $(n=39, r=-0.2913$, $\left.{ }^{*} p=0.0401\right)$. An enlarged view of $(E)$ in the 0 to $400 \mathrm{fmol} / \mathrm{mg}$ tissue range is shown in (F). (G) Correlation between APP and A $340(n=39$, $r=0.2993, p=0.072)$. $(\boldsymbol{H})$ Correlation between APP and A 42 levels $\left(n=39, r=0.3714,{ }^{*} p=0.0236\right)$. Statistical analysis was performed using the two-tailed Pearson's correlation coefficient. Figure S7. Specificity of the polyclonal goat anti-HCN1 antibody. (A) Competition analysis using glutathione-S-transferase (GST) fused to the 60-amino acid carboxyl terminal region of murine HCN1 (mHCN1 C60). This region of the protein contains the epitope for the goat anti-HCN1 antibody used in this study (sc-19706: Santa Cruz Biotechnology). Brain lysates (10 $\mu \mathrm{g}$ protein) derived from $\mathrm{HCN}^{+/+}$and $\mathrm{HCN}^{-1-}$ mice and cynomolgus monkeys were subjected to immunoblot analysis. The anti-HCN1 antibody was preincubated with $20 \mu \mathrm{g}$ GST alone or GST-mHCN1 C60 recombinant protein at $4^{\circ} \mathrm{C}$ for $2 \mathrm{~h}$. The pre-incubated antibody was then reacted with the immunoblots. $\mathrm{HCN} 1$ was detected in $\mathrm{HCN}^{+/+}$mouse and monkey brains when the antibody was pre-incubated with GST alone, but not when the antibody was pre-incubated with GST-mHCN1 C60. (B) Titer comparison between anti-HCN1 antibodies. Brain lysates (10 $\mu \mathrm{g}$ protein) were subjected to immunoblot analysis with two commercial anti-HCN1 antibodies (sc-19706, Santa Cruz Biotechnology; and AB5884, Millipore). (C) Specificity of goat anti-HCN1 antibody (sc-19706) for immunohistochemical analysis. $(\boldsymbol{a}, \boldsymbol{b})$ Representative images of horizontal brain sections showing the hippocampal formation in 13-week-old $\mathrm{HCN1}^{+/+}$(a) and $\mathrm{HCN1}^{-1-}$ (b) mice stained with goat antiHCN1 antibody, followed by donkey anti-goat IgG coupled with FITC. $(\boldsymbol{c}, \boldsymbol{d})$ Magnified view of the squares in $(\boldsymbol{a})$ and $(\boldsymbol{b})$. HCN1 signals (green) observed in $\mathrm{HCN}^{+/+}$mice were absent in $\mathrm{HCN1}^{-1-}$ mice. Nuclei counter-stained with DAPI are shown in blue. Scale bars, $300 \mu \mathrm{m}(a, b)$, $50 \mu \mathrm{m}(c, d)$.

Additional file 2: Movie S1. Spontaneous epileptic seizures in $\mathrm{X}_{1} 1^{-1}$ / $\mathrm{X} 11 \mathrm{~L}^{-/-}$mice. The electrocorticogram of Supplementary Figure $\mathrm{S} 1$ and Movie S3 were simultaneously recorded.

Additional file 3: Movie S2. Spontaneous epileptic seizures in $\mathrm{X}_{1} 1^{-1}$ $\mathrm{X} 11 \mathrm{~L}^{-/-}$mice. The electrocorticogram of Supplementary Figure S1 and Movie S3 were simultaneously recorded.

Additional file 4: Movie S3. Spontaneous epileptic seizures in $\mathrm{X}_{11^{-1} \text { / }}$ $\mathrm{X} 11 \mathrm{~L}^{-1-}$ mice. The electrocorticogram of Supplementary Figure S1 and Movie S3 were simultaneously recorded. 


\section{Abbreviations}

ACSF: Artificial cerebrospinal fluid; AD: Alzheimer's disease; APP: Amyloid precursor protein; $A B$ : Amyloid $\beta$ peptide; DG: Dentate gyrus; $E C$ : Entorhinal cortex; FBS: Fetal bovine serum; HCN channel: Hyperpolarization-activated cyclic nucleotide gated channel; Ih current: Hyperpolarization-activated current; PBS: Phosphate buffered saline; SAPP: Soluble APP; SDS: Sodium dodecyl sulfate; SELISA: Sandwich ELISA; SDS-PAGE: SDS polyacrylamide gel electrophoresis; TBS: Tris buffere saline; X11L: X11-like; X11L2: X11-like2; X11s: X11 proteins.

\section{Competing interests}

The authors declare no competing interests.

\section{Authors' contributions}

YS, TI, GZ, MO, KI, SK and TS generated the hypotheses for the mouse, monkey and human projects. YS and TS drafted the manuscript. YS, TI, GZ, MO, MN, SK, RS, Kl, and TS edited the manuscript and contributed to discussion. YS and NK performed the biochemical and histochemical analyses for the mouse and monkey studies. YS, MN and SM performed biochemical analyses for the human study. TI and KI conducted electrophysiological analyses for the mouse study. YS, GZ, MO and SK performed electroencephalogram recordings. MN and NK provided monkey tissues, and SM provided human tissues. All authors read and approved the final manuscript.

\section{Acknowledgements}

This study was supported in part by a Grant-in-Aid for Research Activity Start-up (21890002) and by a Grant-in-Aid for Young Scientists (B) (23790069) from the Japan Society for the Promotion of Science (JSPS) to YS. YS was also supported by the Akiyama Life Science Foundation and the Regional R\&D Proposal-Based Program from the Northern Advancement Center for Science \& Technology of Hokkaido, Japan. TS was supported in part by Grants-in-aid for Scientific Research $(2339001,2311370,22659011)$ from the Ministry of Education, Culture, Sports, Science and Technology (MEXT) of Japan, and by a grant from the Ministry of Health, Labor and Welfare (MHLW) of Japan.

\section{Author details}

${ }^{1}$ Laboratory of Neuroscience, Graduate School of Pharmaceutical Sciences, Hokkaido University, Kita12-Nishi6, Kita-ku, Sapporo 060-0812, Japan. ${ }^{2}$ Laboratory of Neurobiophysics, Graduate School of Medicine, Dentistry and Pharmaceutical Sciences, Okayama University, Okayama 700-8530, Japan. ${ }^{3}$ Department of Psychiatry, The First Affiliated Hospital of China Medical University, Shenyang 110001, China. ${ }^{4}$ Division of Neuroscience, Graduate School of Medicine, Mie University, Tsu 514-8507, Japan. ${ }^{5}$ Molecular Neuroscience Research Center, Shiga University of Medical Science, Otsu 520-2192, Japan. 'Laboratory of Disease Control, Tsukuba Primate Research Center, National Institute of Biomedical Innovation, Tsukuba 305-0843, Japan. ${ }^{7}$ Department of Neuropathology, Tokyo Metropolitan Institute of Gerontology, Itabashi-ku, Tokyo 173-0015, Japan. ${ }^{8}$ Brain Bank for Aging Research, Tokyo Metropolitan Institute of Gerontology, Itabashi-ku, Tokyo 173-0015, Japan. ${ }^{9}$ Departments of Neuropsychiatry, Graduate School of Medicine, Hirosaki University, Hirosaki 036-8562, Japan. ${ }^{10}$ Division of Cerebral Structure, National Institute for Physiological Sciences, Okazaki 444-8585, Japan. "Department of Information Physiology, National Institute for Physiological Sciences, Okazaki 444-8787, Japan.

Received: 12 April 2012 Accepted: 27 September 2012 Published: 3 October 2012

\section{References}

1. Selkoe DJ: Alzheimer's disease is a synaptic failure. Science 2002, 298:789-791.

2. Hauser WA, Morris ML, Heston LL, Anderson VE: Seizures and myoclonus in patients with Alzheimer's disease. Neurology 1986, 36:1226-1230.

3. Hesdorffer DC, Hauser WA, Annegers JF, Kokmen E, Rocca WA: Dementia and adult-onset unprovoked seizures. Neurology 1996, 46:727-730.

4. Mendez M, Lim G: Seizures in elderly patients with dementia: epidemiology and management. Drugs Aging 2003, 20:791-803.
5. Amatniek JC, Hauser WA, DelCastillo Castaneda C, Jacobs DM, et al: Incidence and predictors of seizures in patients with Alzheimer's disease. Epilepsia 2006, 47:867-872.

6. Lozsadi DA, Larner AJ: Prevalence and causes of seizures at the time of diagnosis of probable Alzheimer's disease. Dement Geriatr Cogn Disord 2006, 22:121-124.

7. Marcon G, Giaccone G, Cupidi C, Balestrieri M, Beltrami CA, et al: Neuropathological and clinical phenotype of an Italian Alzheimer family with M239V mutation of presenilin 2 gene. J Neuropathol Exp Neurol 2004, 63:199-209.

8. Kamenetz F, Tomita T, Hsieh H, Seabrook G, Borchelt D, et al: APP processing and synaptic function. Neuron 2003, 37:925-937.

9. Cirrito JR, Yamada KA, Finn MB, Sloviter RS, Bales KR, et al: Synaptic activity regulates interstitial fluid amyloid-beta levels in vivo. Neuron 2005, 48:913-922.

10. Cirrito JR, Kang JE, Lee J, Stewart FR, Verges DK, et al: Endocytosis is required for synaptic activity-dependent release of amyloid-beta in vivo. Neuron 2008, 58:42-51.

11. Postea O, Biel M: Exploring HCN channels as novel drug targets. Nat Rev Drug Discov 2011, 10:903-914.

12. Noam Y, Bernald C, Baram TZ: Towards an integrated view of HCN channel role in epilepsy. Curr Opin Neurobiol 2011, 21:873-879.

13. Kimura K, Kitano J, Nakajima Y, Nakanishi S: Hyperpolarization-activated cyclic nucleotide-gated HCN2 cation channel forms a protein assembly with multiple neuronal scaffold proteins in distinct modes of proteinprotein interaction. Genes Cells 2004, 9:631-640.

14. Suzuki T, Nakaya T: Regulation of amyloid $\beta$-protein precursor by phosphorylation and protein interaction. J Biol Chem 2008, 283:29633-29637.

15. Borg JP, Yang Y, De Taddeo Borg M, Margolis B, Turner RS: The X11alpha protein slows cellular amyloid precursor protein processing and reduces Abeta40 and Abeta42 secretion. J Biol Chem 1998, 273:14761-14766.

16. Tomita S, Ozaki T, Taru H, Oguchi S, Takeda S, et al: Interaction of a neuron-specific protein containing PDZ domains with Alzheimer's amyloid precursor protein. J Biol Chem 1999, 274:2243-2254.

17. Lee JH, Lau KF, Perkinton MS, Standen CL, Shemilt SJ, et al: The Neuronal Adaptor Protein X11a Reduces A 3 Levels in the Brains of Alzheimer's APPswe Tg2576 Transgenic Mice. J Biol Chem 2003, 278:47025-47029.

18. Lee JH, Lau KF, Perkinton MS, Standen CL, Rogelj B, et al: The neuronal adaptor protein $\mathrm{X} 11$ beta reduces amyloid beta-protein levels and amyloid plaque formation in the brains of transgenic mice. J Biol Chem 2004, 279:49099-49104.

19. Mitchell JC, Ariff BB, Yates DM, Lau KF, Perkinton MS, et al: X11 beta rescues memory and long-term potentiation deficits in Alzheimer's disease APPswe Tg2576 mice. Hum Mol Genet 2009, 18:4492-4500.

20. Sano Y, Syuzo-Takabatake A, Nakaya T, Saito Y, Tomita S, et al: Enhanced amyloidogenic metabolism of the amyloid beta-protein precursor in the X11L-deficient mouse brain. J Biol Chem 2006, 281:37853-37860.

21. Saito $Y$, Sano $Y$, Vassar R, Gandy S, Nakaya T, et al: X11 proteins regulate the translocation of amyloid beta-protein precursor (APP) into detergent-resistant membrane and suppress the amyloidogenic cleavage of APP by beta-site-cleaving enzyme in brain. J Biol Chem 2008, 283:35763-35771.

22. Kondo M, Shiono M, Itoh G, Takei N, Matsushima T, et al: Increased amyloidogenic processing of transgenic human APP in X11-like deficient mouse brain. Mol Neurodegener 2010, 5:35.

23. Morimoto K, Fahnestock M, Racine RJ: Kindling and status epilepticus models of epilepsy: rewiring the brain. Prog Neurobiol 2004, 73:1-60.

24. van Strien NM, Cappaert NL, Witter MP: The anatomy of memory: an interactive overview of the parahippocampal-hippocampal network. Nat Rev Neurosci 2009, 10:272-282.

25. Notomi T, Shigemoto R: Immunohistochemical localization of Ih channel subunits, HCN1-4, in the rat brain. J Comp Neurol 2004, 471:241-276.

26. Ludwig A, Budde T, Stieber J, Moosmang S, Wahl C, et al: Absence epilepsy and sinus dysrhythmia in mice lacking the pacemaker channel HCN2. EMBO J 2003, 22:216-224.

27. Huang Z, Walker MC, Shah MM: Loss of dendritic HCN1 subunits enhances cortical excitability and epileptogenesis. J Neurosci 2009, 29:10979-10988. 
28. Nolan MF, Dudman JT, Dodson PD, Santoro B: HCN1 channels control resting and active integrative properties of stellate cells from layer II of the entorhinal cortex. J Neurosci 2007, 27:12440-12451.

29. Setou M, Nakagawa T, Seog DH, Hirokawa N: Kinesin superfamily motor protein KIF17 and mLin-10 in NMDA receptor-containing vesicle transport. Science 2000, 288:1796-1802.

30. Saito $Y$, Akiyama M, Araki Y, Sumioka A, Shiono M, et al: Intracellular Trafficking of the Amyloid $\beta$-Protein Precursor (APP) Regulated by Novel Function of X11-Like. PLoS One 2011, 6:e22108.

31. Braak H, Braak E: Neuropathological stageing of Alzheimer-related changes. Acta Neuropathol 1991, 82:239-259.

32. Nakamura S, Nakayama H, Goto N, Ono F, Sakakibara I, Yoshikawa Y: Histopathological studies of senile plaques and cerebral amyloidosis in cynomolgus monkeys. J Med Primatol 1998, 27:244-252.

33. Oikawa N, Kimura N, Yanagisawa K: Alzheimer-type tau pathology in advanced aged nonhuman primate brains harboring substantial amyloid deposition. Brain Res 2010, 1315:137-149.

34. Podlisny MB, Tolan DR, Selkoe DJ: Homology of the amyloid $\beta$ protein precursor in monkey and human supports a primate model for $\beta$ amyloidosis in Alzheimer's disease. Am J Pathol 1991, 138:1423-1435.

35. Rogelj B, Mitchell JC, Miller CCJ, McLoughlin DM: The X11/Mint family of adaptor proteins. Brain Res Rev 2006, 52:305-315.

36. Shah MM, Anderson AE, Leung $V$, Lin $X$, Johnston D: Seizure-induced plasticity of h channels in entorhinal cortical layer III pyramidal neurons. Neuron 2004, 44:495-508.

37. Powell KL, Ng C, O'Brien TJ, Xu SH, Williams DA, et al: Decreases in HCN mRNA expression in the hippocampus after kindling and status epilepticus in adult rats. Epilepsia 2008, 49:1686-1695.

38. Bender RA, Soleymani SV, Brewster AL, Nguyen ST, Beck H, et al: Enhanced expression of a specific hyperpolarization-activated cyclic nucleotidegated cation channel (HCN) in surviving dentate gyrus granule cells of human and experimental epileptic hippocampus. J Neurosci 2003, 23:6826-6836.

39. Brewster A, Bender RA, Chen Y, Dube C, Eghbal Ahmadi M, Baram TZ: Developmental febrile seizures modulate hippocampal gene expression of hyperpolarization-activated channels in an isoform- and cell-specific manner. J Neurosci 2002, 22:4591-4599.

40. Dugladze T, Vida I, Tort AB, Gross A, Otahal J, et al: Impaired hippocampal rhythmogenesis in a mouse model of mesial temporal lobe epilepsy. Proc Natl Acad Sci USA 2007, 104:17530-17535.

41. Jung S, Jones TD, Lugo JN Jr, Sheerin AH, Miller JW, et al: Progressive dendritic HCN channelopathy during epileptogenesis in the rat pilocarpine model of epilepsy. J Neurosci 2007, 27:13012-13021.

42. Shin M, Brager D, Jaramillo TC, Johnston D, Chetkovich DM: Mislocalization of $\mathrm{h}$ channel subunits underlies $\mathrm{h}$ channelopathy in temporal lobe epilepsy. Neurobiol Dis 2008, 32:26-36.

43. Marcelin B, Chauviere L, Becker A, Migliore M, Esclapez M, Bernard C: $\mathrm{h}$ channel-dependent deficit of theta oscillation resonance and phase shift in temporal lobe epilepsy. Neurobiol Dis 2009, 33:436-447.

44. Nie Z, Hirsch DS, Randazzo PA: Arf and its many interactors. Curr Opin Cell Biol 2003, 15:396-404

45. Teber I, Nagano F, Kremerskothen J, Bilbilis K, Goud B, Barnekow A: Rab6 interacts with the mint3 adaptor protein. Biol Chem 2005, 386: 671-677.

46. Araki $Y$, Tomita $S$, Yamaguchi $H$, Miyagi N, Sumioka A, et al: Novel cadherinrelated membrane proteins, Alcadeins, enhance the $\mathrm{X} 11$-like proteinmediated stabilization of amyloid beta-protein precursor metabolism. J Biol Chem 2003, 278:49448-49458.

47. Araki Y, Kawano T, Taru H, Saito Y, Wada S, et al: The novel cargo Alcadein induces vesicle association of kinesin-1 motor components and activates axonal transport. EMBO J 2007, 26:1475-1486.

48. Kakuda N, Shoji M, Arai H, Furukawa K, Ikeuchi T, et al: Altered $\gamma$-secretase activity in mild cognitive impairment and Alzheimer's disease. EMBO Mol Med 2012, 4:344-352.

49. Ishii TM, Takano M, Ohmori H: Determinants of activation kinetics in mammalian hyperpolarization-activated cation channels. J Physiol 2001, 537:99-100

50. Zhu G, Okada M, Yoshida S, Ueno S, Mori F, et al: Rats harboring S284L Chrna4 mutation show attenuation of synaptic and extrasynaptic
GABAergic transmission and exhibit the nocturnal frontal lobe epilepsy phenotype. J Neurosci 2008, 28:12465-12376.

51. Dickson CT, Magistretti J, Shalinsky MH, Fransen E, Hasselmo ME, Alonso A: Properties and role of $\mathrm{I}(\mathrm{h})$ in the pacing of subthreshold oscillations in entorhinal cortex layer II neurons. J Neurophysiol 2000, 83:2562-2579.

doi:10.1186/1750-1326-7-50

Cite this article as: Saito et al:: Hyperpolarization-activated cyclic nucleotide gated channels: a potential molecular link between epileptic seizures and $A \beta$ generation in Alzheimer's disease. Molecular

Neurodegeneration 2012 7:50.

\section{Submit your next manuscript to BioMed Central and take full advantage of:}

- Convenient online submission

- Thorough peer review

- No space constraints or color figure charges

- Immediate publication on acceptance

- Inclusion in PubMed, CAS, Scopus and Google Scholar

- Research which is freely available for redistribution 